\title{
Integrating Urban Form, Function, and Energy Fluxes in a Heat Exposure Indicator in View of Intra-Urban Heat Island Assessment and Climate Change Adaptation
}

\author{
Ilias Agathangelidis ${ }^{1, *}$, Constantinos Cartalis ${ }^{1}$ and Mat Santamouris ${ }^{2}$ \\ 1 Department of Physics, National and Kapodistrian University of Athens, 15784 Athens, Greece; \\ ckartali@phys.uoa.gr \\ 2 Anita Lawrence Chair High Performance Architecture, Faculty of Built Environment, \\ University of New South Wales, 2033 Sydney, Australia; m.santamouris@unsw.edu.au \\ * Correspondence: iliasaga@phys.uoa.gr; Tel.: +30-210-727-6774
}

Received: 19 April 2019; Accepted: 24 May 2019; Published: 28 May 2019

\begin{abstract}
Cities worldwide are getting warmer due to the combined effects of urban heat and climate change. To this end, local policy makers need to identify the most thermally vulnerable areas within cities. The Local Climate Zone (LCZ) scheme highlights local-scale variations; however, its classes, although highly valuable, are to a certain extent generalized in order to be universally applicable. High spatial resolution indicators have the potential to better reflect city-specific challenges; in this paper, the Urban Heat Exposure (UHeatEx) indicator is developed, integrating the physical processes that drive the urban heat island (UHI). In particular, the urban form is modeled using remote sensing and geographical information system (GIS) techniques, and used to estimate the canyon aspect ratio and the storage heat flux. The Bowen ratio is calculated using the aerodynamic resistance methodology and downscaled remotely sensed surface temperatures. The anthropogenic heat flux is estimated via a synergy of top-down and bottom-up inventory approaches. UHeatEx is applied to the city of Athens, Greece; it is correlated to air temperature measurements and compared to the LCZs classification. The results reveal that UHeatEx has the capacity to better reflect the strong intra-urban variability of the thermal environment in Athens, and thus can be supportive for adaptation responses. High-resolution climate projections from the EURO-CORDEX ensemble for the region show that the adverse effects of the existing thermal inequity are expected to worsen in the coming decades.
\end{abstract}

Keywords: urban heat island; local climate zones; surface energy balance; anthropogenic heat flux; urban thermal indicator; climate change

\section{Introduction}

Over two-thirds of the world's population are projected to dwell in urban areas by 2050 [1], reflecting the continuously growing role of cities as centers of human and economic activity. Among other environmental concerns, such as ambient/indoor air pollution and waste management, cities experience elevated air temperatures relative to their surrounding rural areas [2], which is a phenomenon commonly referred to as the urban heat island (UHI). The thermal effect of a city is mainly related to [3]: (a) the urban form - the fabric, the surface cover, and the three-dimensional urban structure - and (b) the urban function-the waste heat resulting from human activities. Numerous studies have been conducted in the last decades measuring the urban canopy layer UHI (UHI $\mathrm{UCL}_{\mathrm{C}}$ ) (e.g., [4-6]) and estimating the surface UHI (SUHI) (e.g., [7-9]). Urban overheating is found to have a strong relation to increased energy consumption for cooling $[10,11]$ and heat-stress related morbidity 
and mortality [12-15]. During heat wave events, urban heat has been proven a serious health hazard also for residents of usually cooler mid-latitude and high-latitude cities [16,17]. Global climate change further exacerbates the impact of the UHI, as it causes the warming of the climate system and makes the future occurrence of heat waves with higher frequency and duration very likely [18]. Initiatives for UHI mitigation/adaptation are being interlinked with climate change policies [19], and cities are gaining a central role in current global agreements, such as the recent Paris Agreement (2015) of the United Nations Framework Convention on Climate Change (UNFCCC).

Climate change $[20,21]$ and more generally enhanced heat stress $[22,23]$ do not affect all citizens of a city to the same degree, due to the intra-urban diversity of surface microclimates and the varying physiological characteristics of the population (e.g., age, state of health). City planners and policy makers need tools to identify the most thermally vulnerable areas of their city before designing and implementing climate policies [24]. The Local Climate Zone (LCZ) [25] categorizes urban areas based on their urban form and function in distinct, neighborhood-scale types that have uniform thermal climates. LCZs can provide valuable insight into the spatial thermal patterns when attributed across a city [26-28]. However, the LCZ classification is primarily focused on universally recognized built arrangements in view of UHI field sites' selection and metadata reporting [25] - the latter being a significant limitation in the existing UHI literature [29]. As a consequence, intraclass thermal variability has been reported in several LCZ studies $[6,30,31]$, which can to a great extent be attributed to the considerable range of surface parameters within each LCZ class [31]. This may hold especially true when LCZ mapping is derived using remote sensing imagery in the World Urban Database and Access Portal Tools (WUDAPT) project [32]. Furthermore, the LCZ scheme might not be necessarily capable of describing specific cases of the often irregular urban form of European cities [33].

An indicator that aggregates the driving forces of UHI can be viewed as an alternative representation of the urban thermal environment. Several studies have used thermal environmental indicators, either as a component within the Urban Climatic Map (UCMap) framework (e.g., [24,34,35]) or as an independent metric (e.g., [22,36,37]). Nevertheless, in most of the relevant indicators, the highly important features of urban form and function are not considered. The three-dimensional complexity of the city is reported to be often missing [38], and dynamic urban processes, such as the turbulent energy exchanges and the anthropogenic heat emissions, are typically not explicitly integrated. Here, a physically based, thermal indicator-the Urban Heat Exposure (UHeatEx) indicator-is proposed. UHeatEx integrates the most important physical processes that have been identified to control local surface climates, modify the surface energy balance, and cause the UHI. These processes are [2,25]:

- High values of the ratio of building's height $(\mathrm{H})$ to street width $(\mathrm{W})$ - canyon aspect ratio $(\mathrm{H} / \mathrm{W})$ - result in canyon trapping [39,40], i.e., the absorption of shortwave radiation in the canopy is stronger via multiple reflections on walls, and in the longwave radiant heat loss being strongly obscured [41,42].

- Sensible heat refers to the direct warming of air that can be sensed by a thermometer, whereas the latent heat component of the urban energy balance is mostly associated with the energy exchanges during surface moisture evaporation. The dry, impermeable urban facets favor sensible $\left(Q_{H}\right)$ over latent $\left(Q_{E}\right)$ heat flux; i.e., the Bowen ratio $\left(\beta=Q_{H} / Q_{E}\right)$ has higher values. As a result, the evaporative cooling effect decreases [43,44].

- High thermal inertia of the construction materials and of the built environment in general results in a large proportion of incoming solar radiation to be stored during the daytime in the urban system — high net heat storage $\left(\Delta Q_{S}\right)$ - and being released at nighttime, maintaining the urban heating effect [45].

- The anthropogenic heat flux $\left(Q_{F}\right)$, e.g., waste heat from vehicular traffic and from space heating/cooling, is an additional energy source into the surface energy balance [46].

These four decisive parameters for the urban climate $\left(\mathrm{H} / \mathrm{W}, \beta, \Delta Q_{S}, Q_{F}\right)$ are estimated in this work using meteorological, earth observation, and geographical information system (GIS) data; the 
different variables are subsequently incorporated in the UHeatEx composite indicator via principal component analysis (PCA). An additional mapping of the study area using the LCZ scheme is applied, and similarities and differences between UHeatEx and LCZs are discussed. Both results are correlated with air temperature measurements from a network of automatic weather stations (AWSs) in the area under examination, for a six-year period (the warm period months). A qualitative and quantitative analysis examines the presence of thermal inequity in Athens and its relationship with socioeconomic characteristics. The growing importance of thermal indicators in sustainable urban planning, due to climate change, is demonstrated by presenting the simulated future conditions of the city. To this end, high-resolution climate projections from an ensemble of regional climate models (RCMs) were used.

\section{Materials and Methods}

\subsection{Study Area}

The study site of this work is the Athens agglomeration (hereafter referred to as Athens), including the cities of Athens and Piraeus, and their suburbs; it is located at the central part of Greece, at the south end of the Attica peninsula and covers a total area of $414.6 \mathrm{~km}^{2}$ (Figure 1). Athens has a subtropical Mediterranean climate with mild winters and hot, dry summers; however, both heating and cooling demands are significant [47]. For the first post-war decades, a rapid densification took place in the central and western parts of the city; since the mid-1970s, urbanization has shifted to a less intense suburban expansion to the northeastern and southeastern districts [48]. The prevailing building types in Athens are flat-roofed, light-colored, multi-story apartments, using cement as the prevailing construction material [49]. The high thermal mass that is associated with these buildings, the scarce green infrastructure [50], and the narrow streets contribute to the development of a strong UHI in a large part of Athens [51-53].

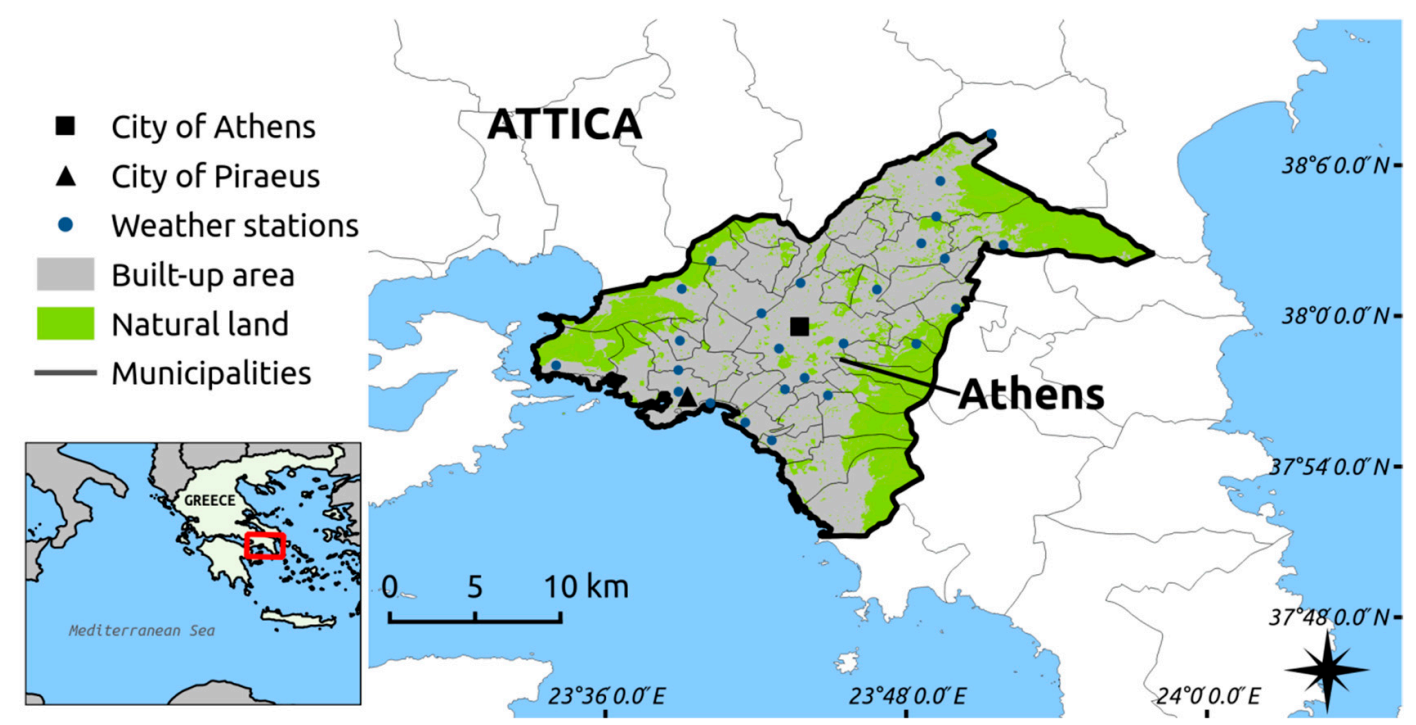

Figure 1. Location of the study area: Athens, Greece; land use information from Urban Atlas [54].

\subsection{Urban Form}

A detailed spatial mapping of the urban form (fabric, land cover, geometric structure) is necessary for the estimation of $\mathrm{H} / \mathrm{W}$ and for the required ancillary data regarding the calculation of the urban energy fluxes. A high-resolution land cover classification was used that distinguishes 10 man-made and natural materials [55]; the classification was derived using a machine learning approach integrating the 10-meter resolution bands of the Sentinel-2 satellite, land use information, and digital elevation models. Building footprints were available from the Hellenic Statistical Authority (ELSTAT) [56] and the OpenStreetMap project [57]. Very high-resolution digital elevation models—a 0.8-meter resolution 
digital surface model (DSM) and a five-meter resolution digital terrain model (DTM)-were provided from the Greek land registry service (Hellenic Cadastre). Using the above data sources, the height of urban elements and the plan-area fraction of buildings $\left(\lambda_{b}\right)$, floors of buildings $\left(\lambda_{\text {floors }}\right)$, impervious ground surface $\left(\lambda_{\mathrm{i}}\right)$, vegetation $\left(\lambda_{\mathrm{v}}\right)$, and soil $\left(\lambda_{\mathrm{s}}\right)$ were calculated. An automated extraction of the $\mathrm{H} / \mathrm{W}$ parameter is challenging, as a result of the high complexity of urban patterns; to this end, the consideration of linear traverses at different angles [58,59] and of local distance maxima [60] have been previously used. A new approach was followed here, employing the urban block unit and making use of standard GIS algorithms (Figure 2): (a) buildings were first assigned to their respected urban blocks and the minimum convex containing the buildings of each block (i.e., the convex hull) was constructed; (b) then, buildings were attributed to their adjacent convex sides and a corresponding mean $\mathrm{H}$ for each side was computed; (c) road segments were formed as the centerlines between opposite convex sides (estimated using Voronoi diagrams); (d) H/W was finally computed as the ratio of the mean $\mathrm{H}$ adjacent to the road to twice the distance of the convex side to the centerline (road and sidewalk width). For open areas and irregular building arrangements, $\mathrm{H} / \mathrm{W}$ was estimated using the spacing of buildings in the place of $W$. The frontal aspect ratio $\left(\lambda_{f}\right)$ was calculated from the projected area of windward facets to the wind for different wind angles (per $15^{\circ}$ ) $[59,61,62]$. Surface thermal emissivity and surface reflectance were derived from [55]: (a) emissivity was estimated with a land cover-based approach using the above-mentioned 10-meter resolution classification and emissivity values from spectral libraries; (b) for surface reflectance, the Landsat 5 and 8 Surface Reflectance on-demand product was used, which was obtained from the United States Geological Survey (USGS) Earth Explorer portal. Digital elevation models were not available for the natural zones on the city outskirts (see Figure 1); thus, the properties of the urban form-and as a consequence, all the subsequently derived variables-were not estimated for these areas. All the finer-scale parameters were aggregated using a weighted area average to a $100 \times 100$ grid.
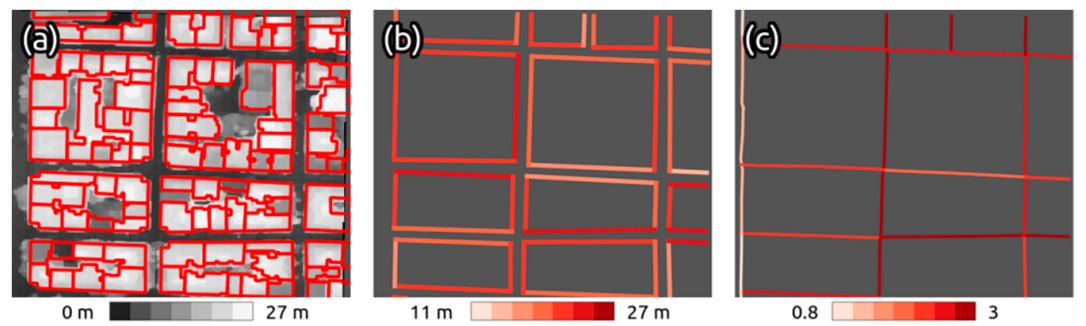

Figure 2. Canyon aspect ratio, height to street width $(\mathrm{H} / \mathrm{W})$ estimation: (a) raster layer of height $[\mathrm{m}]$ of the urban elements at $0.8-\mathrm{m}$ resolution, red lines indicate the building footprints, (b) mean height [m] of each convex side enclosing buildings and (c) $\mathrm{H} / \mathrm{W}$ of each road segment.

\subsection{Bowen Ratio}

Remote sensing methods have often been used in natural [63-65] and urban environments [66-68] for the estimation of the turbulent surface fluxes using the aerodynamic resistances for heat $\left(r_{H}\right)$ [s $\left.\mathrm{m}^{-1}\right]$ and moisture $\left(r_{V}\right)\left[\mathrm{s} \mathrm{m}^{-1}\right]$ transfer:

$$
\begin{aligned}
Q_{H} & =\rho_{\alpha} c_{p} \frac{T_{s}-T_{a}}{r_{H}}\left[\mathrm{~W} \mathrm{~m}^{-2}\right], \\
Q_{E} & =\rho_{\alpha} L_{V} \frac{q_{s}-q}{r_{V}}\left[\mathrm{~W} \mathrm{~m}^{-2}\right],
\end{aligned}
$$

where $\rho_{\alpha}$ is the air density $\left[\mathrm{kg} \mathrm{m}^{-3}\right], c_{p}$ is the specific heat of air at constand pressure $\left[\mathrm{J} \mathrm{kg}^{-1} \mathrm{~K}^{-1}\right]$, $T_{S}$ is the surface temperature $[\mathrm{K}], T_{\alpha}$ is the air temperature $[\mathrm{K}], L_{v}$ is the latent heat of vaporization [J kg-1 $], q_{s}$ is the saturation specific humidity at $T_{s}\left[\mathrm{~kg} \mathrm{~kg}^{-1}\right]$, and $\mathrm{q}$ is the specific humidity of air $\left[\mathrm{kg} \mathrm{kg}^{-1}\right] . T_{S}$ was estimated from Moderate Resolution Imaging Spectroradiometer (MODIS) radiances, downscaled to $100 \mathrm{~m}$ and converted to surface temperature using a statistical downscaling 
methodology that combines ridge regression with multiple predictor variables and a high-resolution emissivity map [55]. MODIS calibrated radiances product (MOD/MYD021KM) and precipitable water product (MOD/MYD05-L2) were accessed from the National Aeronautics and Space Administration's (NASA's) Level-1 and Atmosphere Archive and Distribution System (LAADS) Distributed Active Archive Center (DAAC). Above rooftop level meteorological data- $T_{\alpha}$, barometric pressure (P), wind speed $(\mathrm{W})$, relative humidity $(\mathrm{RH})$, and downward solar radiation $(\mathrm{K} \downarrow)$-were provided from the network of urban AWSs of the National Observatory of Athens via its online interface ([69]; http://stratus.meteo.noa.gr/front; Figure 1). These data were subsequently interpolated in the study area using regression kriging with elevation as an auxiliary variable [70] ( $\downarrow \downarrow$ was considered constant for the whole study area). The $r_{H}$ resistance parameter —including the friction velocity $(u *)$-was calculated as [66] with the following parameterizations: (a) the roughness length for momentum $\left(\mathrm{z}_{0}\right)$ and the zero plane displacement level $\left(\mathrm{z}_{\mathrm{d}}\right)$ were calculated from a recent modification of Macdonald et al.'s morphometric method [71], which was presented in [72]; (b) the roughness length for heat was estimated from [73] for the predominantly urban $\left(\lambda_{\mathrm{V}}<5 \%\right)$ and from [74] for the mixed pixels, respectively. For $r_{V}$, the formulation of [75] and the parameter values for the minimum stomatal resistance $\left(r_{\text {smin }}\right)$ in [76] were used. Roughness sublayer (RSL) stability corrections and the Obukhov length (L) were calculated following [77]. Daily midday ( 12:00 local time) $\beta$ values $\left(\beta_{\mathrm{m}}\right)$ were calculated for the cloud-free MODIS-TERRA thermal imagery of July 2017. A minimum midday magnitude of $5 \mathrm{~W} \mathrm{~m}^{-2}$ was set for $Q_{E}$, in order to account for unmapped subpixel vegetation and avoid infinite $\beta_{\mathrm{m}}$ values. Eddy covariance (EC) is a micrometeorological technique that allows the direct measurement of vertical turbulent fluxes, using the high-frequency data of the vertical velocity component, along with the scalar quantities of the corresponding atmospheric parameters. Employing this method, the validation of $Q_{H}$ and $Q_{E}$ was performed using flux tower measurements from the European Space Agency (ESA) Thermopolis campaign that took place at the Athens city center in July 2009 (tower measurements conducted from 18 to 27 July) $[78,79]$. The fast-response measurements of wind, temperature, and humidity, as performed by the Democritus University of Thrace (DUTH) and provided for this work by ESA (https://earth.esa.int/web/guest/campaigns), were preprocessed using standard eddy covariance flux corrections [79] employing the processing code from [80]. Turbulent fluxes were subsequently derived from:

$$
\begin{aligned}
& Q_{H}=\rho_{\alpha} c_{a} \overline{w^{\prime} \theta \prime}\left[\mathrm{W} \mathrm{m}^{-2}\right], \\
& Q_{E}=\rho_{\alpha} L_{V} \overline{w^{\prime} q^{\prime}}\left[\mathrm{W} \mathrm{m}^{-2}\right],
\end{aligned}
$$

where $w^{\prime}\left[\mathrm{ms}^{-1}\right], \theta^{\prime}[\mathrm{K}]$, and $q^{\prime}\left[\mathrm{kgkg}^{-1}\right]$ represent the short-term fluctuations of vertical wind, potential temperature, and specific humidity respectively. The adjacent half-hour intervals to the corresponding satellite overpasses were used, in order to reduce the large fluctuations of EC measurements [81]. Turbulent flux source areas were estimated from the Korman and Meixner footprint model [82] using the Urban Multi-scale Environmental Predictor (UMEP) GIS tool [83].

\subsection{Net Storage Heat Flux}

Heat storage uptake and release in urban systems is typically estimated using one of the following techniques: the Objective Hysteresis Model (OHM) [45,84], the modeling of heat transfer through urban surfaces $[68,85]$, or the closure of the surface energy balance $[86,87]$. The OHM methodology is a robust approach that provides accurate estimates compared to observational data, especially when the representation of the typical average storage magnitude, rather than its short-term fluctuations, is of primary concern [88]. Considering the contribution of individual surface types (k), OHM can be applied as:

$$
\Delta Q_{S}=\sum_{k=1}^{n} f_{k}\left[a_{1 k} Q^{*}+a_{2 k} \frac{\partial Q^{*}}{\partial t}+a_{3 k}\right]\left[\mathrm{W} \mathrm{m}^{-2}\right]
$$


where $Q^{*}$ is the net radiation flux $\left[\mathrm{W} \mathrm{m}^{-2}\right], \mathrm{f}$ is the fractional cover of the different surfaces (estimated from data in Section 2.2) and $\mathrm{a}_{1}, \mathrm{a}_{2}$, and $\mathrm{a}_{3}$ are the OHM model coefficients (Table 1). $Q^{*}$ is calculated as in [89], using the surface parameters, the remote sensing data, and the atmospheric variables presented in Sections 2.2 and 2.3. The average daily course of $Q^{*}$ for the cloud-free days of July-measured from the World Radiation Centre (WRC) group during the Thermopolis 2009 campaign [78] and included in the previously mentioned ESA dataset-was used to derive the second term in Equation (5). Midday net heat storage values $\left(\Delta Q_{s m}\right)$ were estimated for July 2017, synchronous with the corresponding MODIS-TERRA overpasses.

Table 1. The coefficients for the individual surfaces used in the Objective Hysteresis Model (OHM).

\begin{tabular}{|c|c|c|c|c|}
\hline Surface Type & a1 & a2 [h] & a3 $\left[W \mathrm{~m}^{-2}\right]$ & Source \\
\hline Rooftop & 0.41 & 0.50 & -27.7 & {$[90,91]$} \\
\hline Paved & 0.64 & 0.32 & -43.6 & [92] \\
\hline Canyon & 0.51 & 0.02 & -33.7 & {$[90,93]$} \\
\hline Vegetation & 0.32 & 0.54 & -27.4 & [94] \\
\hline Bare soil & 0.35 & 0.43 & -36.5 & [95] \\
\hline
\end{tabular}

\subsection{Anthropogenic Heat Flux}

Three techniques are commonly employed to estimate $Q_{F}$ [46]: (a) the energy budget residual approach $[68,85,96]$, (b) top-down estimates based on the disaggregation of coarse energy consumption statistics [97-99], and (c) bottom-up estimates that model energy consumption at fine scales [100-102]. A synergy of the latter two methodologies $[103,104]$ can provide the necessary balance between the data availability and required accuracy [105]. This approach was also followed here, with different $Q_{F}$ components being estimated as follows (the year 2012 was selected, where the availability and applicability of all sources was ensured).

\subsubsection{Building Heat Emissions $\left(Q_{F B}\right)$}

Annual electricity consumption was provided by the Hellenic Electricity Distribution Network Operator (HEDNO) per end-use sector and per postal code (234 codes were included within the study area). For the residential and commercial sectors, the consumption data of electricity were first distributed from the postal code area to a 100-meter grid using $\lambda_{\text {floor }}$ as a weighting factor, and the waste heat was subsequently estimated as:

$$
Q_{F B}=\left(\frac{E}{A}\right) F_{E 1} F_{E 2} F_{E 3}\left[\mathrm{~W} \mathrm{~m}^{-2}\right]
$$

where $E$ is the total annual electricity consumption [W] for each grid cell, $A$ is the grid area $\left[\mathrm{m}^{2}\right]$, and $F_{E 1}, F_{E 2}$, and $F_{E 3}$ are scaling factors related to temperature, intra-week, and diurnal variations, respectively. A city-specific temperature response function ([106]; Figure 3a) and daily mean $T_{\alpha}$ (see the description of meteorological data in Section 2.3) were used to calculate $F_{E 1}$. The weekly and diurnal temporal variability $\left(F_{E 2}, F_{E 3}\right)$ were incorporated in the model considering previous research on the electricity consumption of Athens [107,108]; the derived average daily cycles per sector is shown in Figure 3b. Based on [107], temporal profiles were modeled to differ between winter and summer months. In the summer, the late evening peak is lower due to more people being outdoors, and the night minimum is higher as a result of air conditioner usage. The industrial electricity consumption for each postal code was uniformly distributed to the corresponding industrial land use zones, and average load profiles from the Greek Independent Power Transmission Operator (ADMIE) [109] were used. Only aggregated information for heating oil and natural gas consumption was available, from ELSTAT and the Hellenic Gas Transmission System Operator (DESFA) [110]; thus, for these sources, only the city-wide $Q_{F}$ estimates are presented-not influencing the warm period results. Gas daily 
fluctuations (obtained from DESFA [110]) were considered to be befitting for both natural gas and oil consumption (after accounting for the limited, supplementary gas usage, e.g., for cooking).
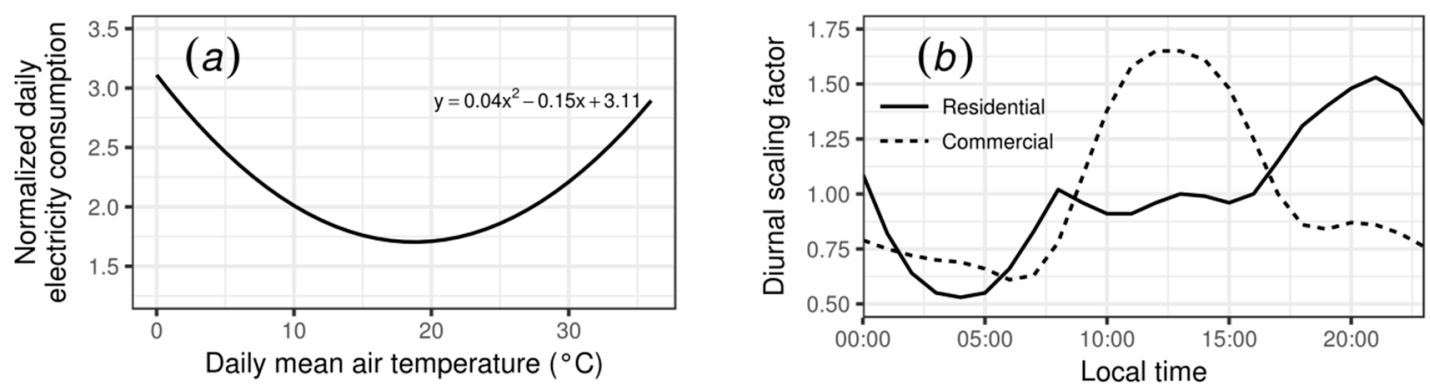

Figure 3. (a) Temperature response function for Athens, modified after [106]; (b) Diurnal scaling factors for electricity consumption per sector (average annual values).

\subsubsection{Vehicular Heat Emissions $\left(Q_{F V}\right)$}

A bottom-up approach was used to model traffic emissions, using: (a) the annual average daily traffic (AADT) from 410 points in the study domain, provided by the Athens Traffic Management Centre (ATMC) and covering mainly the major network roads, and (b) average AADT values per road type derived in the present work after a survey of local municipal traffic studies (Table 2). Road types were determined using OpenStreetMap data [57] and General Urban Planning maps from the Hellenic Ministry of Environment and Energy (YPEKA) [111]. The released heat by the combustion of fuels was computed for each grid cell following [96]:

$$
Q_{F V}=\left(\frac{1}{A}\right) \sum_{i} N_{i} L_{i} V F_{V 1} F_{V 2} F_{V 3}\left[\mathrm{~W} \mathrm{~m}^{-2}\right],
$$

where index $i$ corresponds to different road segments within each cell, $\mathrm{N}$ is the number of vehicles, $\mathrm{L}$ is the road segment length $[\mathrm{m}], \mathrm{V}$ is an emission heat factor $\left[\mathrm{J} \mathrm{m}^{-1}\right]$, and $F_{V 1}, F_{V 2}$, and $F_{V 3}$ are the monthly, weekly, and diurnal scaling factors, respectively. Parameter $V$ was calculated from the estimates of the COPERT tool used in the European Monitoring and Evaluation Programme (EMEP) / European Environment Agency (EEA) air pollutant emission inventory guidebook (2016) [112] using city-specific: (a) vehicle fleet composition from ELSTAT [113], (b) vehicle fuel types from the European Automobile Manufacturers Association (ACEA) [114], and (c) the emission standards of current vehicles from the Hellenic Association of Motor Vehicle Importers-Representatives (AMVIR) [115]. The temporal dynamics of vehicular traffic for Athens $\left(F_{V 1}, F_{V 2}\right.$, and $F_{V 3}$ parameters) were obtained from the Supplementary Material of [116].

Table 2. Annual average daily traffic (AADT) values assignment per road type (per direction).

\begin{tabular}{cc}
\hline Road Classification & AADT \\
\hline Primary & $15,000^{1}$ \\
Secondary & 8000 \\
Tertiary A & 4000 \\
Tertiary B & 2500 \\
Residential & 800
\end{tabular}

${ }^{1}$ All roads with a larger AADT were given a specific value based on available traffic flow measurements.

\subsubsection{Metabolic heat emissions $\left(Q_{F M}\right)$}

The anthropogenic heat flux associated with human metabolism is generally considered a minor component of $Q_{F}$ for mid-latitude cities, accounting for fewer than $5 \%$ of the overall anthropogenic waste 
heat [117]; however, it can get relative large values (up to $45 \%$ of $Q_{F}$ ) for high-density, low-latitude urban areas [118]. The formulation and parameters from [99] were applied for $Q_{F M}$, using the GEOSTAT 2011, gridded $1-\mathrm{km}^{2}$ population data from the Statistical Office of the European Union (EUROSTAT) [119] and subsequent disaggregation through the $\lambda_{\text {floor }}$ parameter.

\subsection{UHeatEx}

The selection of an appropriate weighting scheme to determine the contribution of each individual component is a key factor in the development of composite indicators [120]. PCA is a multivariate statistical technique that can be used for reducing the dimensionality of an original set of variables, estimating the variable weights in order that the maximum proportion of information is preserved [121]. PCA has often been employed in the relevant literature for the development of socioeconomic and environmental indices (e.g., $[36,122,123])$. In this study, the PCA technique was applied to the urban heat-related parameters that were described in the previous sections $\left(\mathrm{H} / \mathrm{W}, \beta, \Delta Q_{S}\right.$, and $\left.Q_{F}\right)$, in order to derive a synthetic urban indicator (UHeatEx). The four above parameters-all positively correlated with a greater risk for urban thermal stress-correspond to the initial set of variable indicators (features) $X=\left[X_{1}, \ldots, X_{p}\right]^{T}$ (here, $\left.p=4\right)$, for which an appropriate weighting scheme is sought through PCA. Since these initial variables are characterized by different units and/or range of values, as a first step, the standardized data matrix $Z=\left[Z_{1}, \ldots, Z_{p}\right]^{T}$ was calculated, subtracting from each variable its arithmetic mean $(\mu)$ and dividing the result by the corresponding standard deviation:

$$
\mathrm{Z}=(\mathrm{D})^{-1}(\mathrm{X}-\mu)
$$

where $\mathrm{D}$ is the diagonal standard deviation matrix. Then, the covariance matrix $\mathrm{R}$ of the transformed standardized variables is calculated as:

$$
\mathrm{R}=\operatorname{Cov}(\mathrm{Z})=\left(\mathrm{D}^{-}\right)^{-1} \mathrm{~K}(\mathrm{D})^{-1},
$$

where $\mathrm{K}$ is the covariance matrix of the initial variables $\mathrm{X}$. PCA is subsequently performed through the eigendecomposition of matrix R:

$$
\mathrm{R}=\mathrm{P} \Lambda \mathrm{P}^{\mathrm{T}},
$$

where $\mathrm{P}$ is a $\mathrm{p} \times \mathrm{p}$ matrix of the eigenvectors e (also referred to as component coefficients or scores) and $\Lambda$ is a diagonal $p \times p$ matrix of the eigenvalues $\lambda$ (with $\lambda \geq 0$ ). The $n^{\text {th }}$ principal component $Y_{n}$ of the set of variables $\mathrm{Z}$ is finally given by:

$$
Y_{n}=e_{n}^{T} Z=e_{1 n} Z_{1}+\ldots+e_{p n} Z_{p}
$$

The first principal component corresponds to those component coefficients (i.e., set of linear weights) that explain the largest possible amount of variation in the original data. The subsequent (three) principal components-which are not linearly correlated with the first principal component or among each other-account for the remaining variation in the image. Thus, through PCA, it is possible to derive that linear combination of the initial variables $\mathrm{H} / \mathrm{W}, \beta, \Delta Q_{S}$, and $Q_{F}$ that achieves the most effective mapping of the spatial variability of the thermal signatures in the study area. As it will be discussed in Section 3, taking into account the physical meaning of the original data, the PCA results, and the final objective of the study, the association of the composite index UHeatEx solely with the derived first principal component was selected. A flowchart illustrating the overall methodology that was followed to derive $\mathrm{H} / \mathrm{W}, \beta, \Delta Q_{s}, Q_{F}$, and UHeatEx is given in Figure 4. 


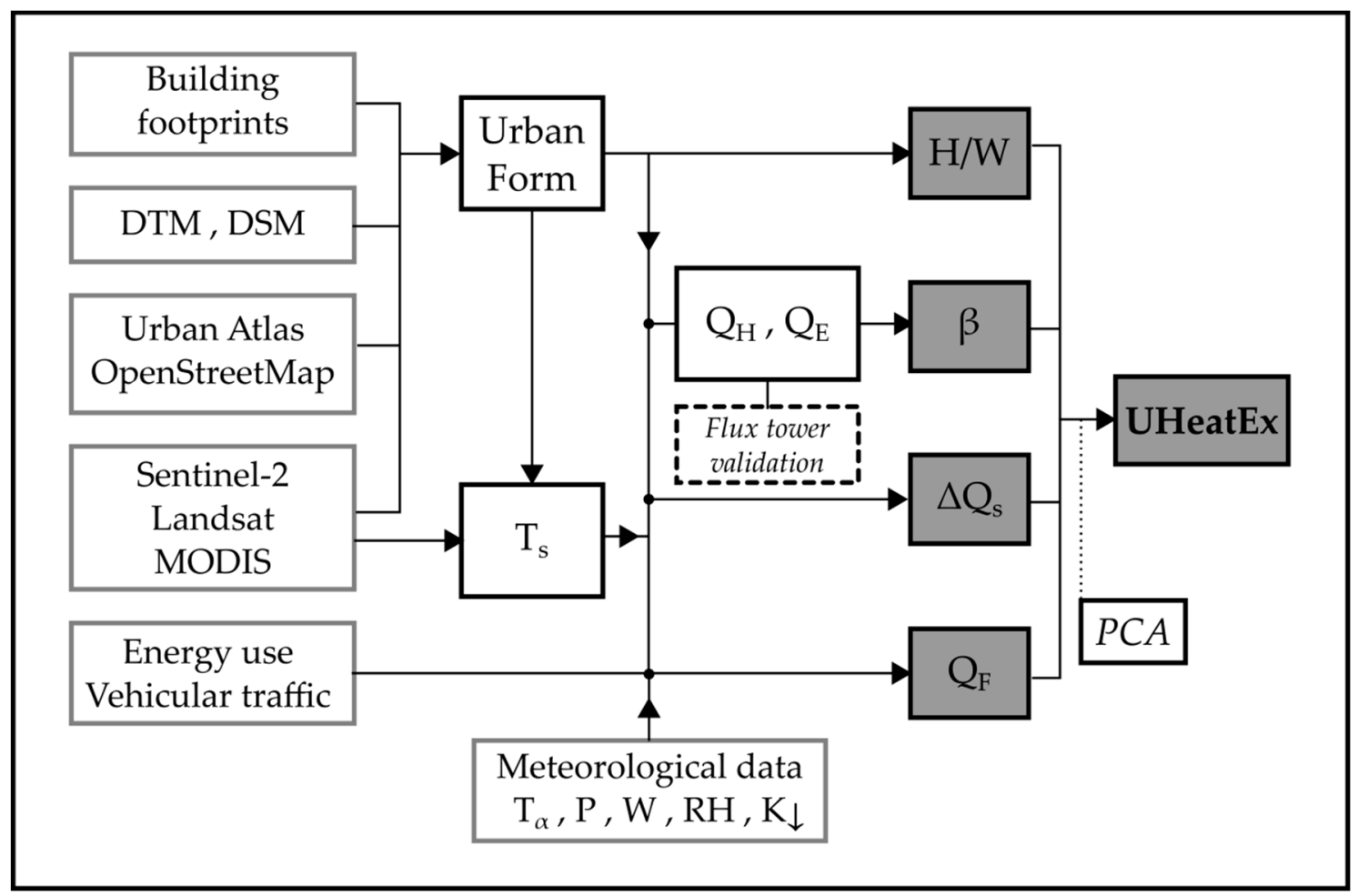

Figure 4. Flowchart of the methodology for the estimation of the Urban Heat Exposure (UHeatEx) indicator. All the notations are given in the text.

\subsection{Local Climate Zones}

A further classification of the study area in the LCZ morphological types was performed. The GIS-based approach [124-127] can provide highly accurate LCZ mapping, as it typically utilizes real urban morphological data [125]. The target resolution of LCZs varies among studies [126]; here, LCZs were estimated at two grid resolutions: (a) at $100 \mathrm{~m}$, which is the resolution that was also used for the UHeatEx indicator, and (b) at $400 \mathrm{~m}$, which corresponds to the minimum LCZ diameter, as suggested in [25]. Using the urban surface properties presented in Section 2.2 and the range of parameter values for each LCZ class [25], the GIS-based method was applied as follows. As a first step, pixels were classified on the basis of whether the urban canyon is their predominant feature-to that end, land use information and a minimum height-to-width threshold $(\mathrm{H} / \mathrm{W}>0.3)$ were used. For pixels corresponding to areas where urban canyons and regular urban blocks arrangements could be found, LCZs were mapped using the non-overlapping thresholds of LCZ parameters. That is, pixels were initially sorted using the urban elements' heights (high-rise, mid-rise, and low-rise types) and subsequently using the H/W (compact and open subtypes), i.e., LCZs 1 to 6 were identified. In the case of detached or irregularly spaced buildings, $\lambda_{b}, \lambda_{i}, \lambda_{v}$, and $\lambda_{s}$ values were used to map the following distinct LCZs: Large low-rise (LCZ 8), Sparsely built (LCZ 9), or one of the natural LCZ classes (LCZs A-G).

\subsection{Climate Change Projections}

Climate change simulations from the current global climate models (GCMs) correspond to a horizontal scale coarser than $100 \mathrm{~km}$; thus, they are generally unsuited for city-scale projections. Dynamical downscaling, in which GCMs are used to drive RCMs at higher resolution, can provide more detailed information about the regional to local climate. In this study, we used 14 high-resolution European Coordinated Regional Downscaling Experiment (EURO-CORDEX) RCM simulations, part of the global Coordinated Regional Downscaling Experiment (CORDEX) project [128] (Table 3). The multi-model mean of the projected near-surface air temperatures at a $0.11^{\circ}$ resolution $(\sim 12.5$ 
km) (EUR-11) was computed for a 50-year period (2021-2070), and the results were averaged for the two grid cells covering the study area. The moderate Representative Concentration Pathway (RCP) 4.5 scenario was selected for the projected greenhouse gases concentrations. The EURO-CORDEX simulations were accessed through the Climate4Impact portal (http://climate4impact.eu).

Table 3. Overview of the European Coordinated Regional Downscaling Experiment (EURO-CORDEX) simulations (EUR-11) used in this study. GCM: global climate model, RCM: regional climate model.

\begin{tabular}{cccc}
\hline & Simulation & RCM & Driving GCM \\
\hline 1 & CLMcom.ICHEC-EC-EARTH & CLM & EC-EARTH \\
2 & CLMcom.MOHC-HadGEM2-ES & CLM & HadGEM2-ES \\
3 & CLMcom.MPI-M-MPI-ESM-LR & CLM & MPI-ESM-LR \\
4 & CLMcom.CNRM-CERFACS-CNRM-CM5 & CLM & CNRM-CM5 \\
5 & DMI.ICHEC-EC-EARTH & HIRHAM5 & EC-EARTH \\
6 & DMI.NCC-NorESM1-M & HIRHAM5 & NorESM1-M \\
7 & KNMI.ICHEC-EC-EARTH & RACMO22E & EC-EARTH \\
8 & KNMI.MOHC-HadGEM2-ES & RACMO22E & HadGEM2-ES \\
9 & SMH.CNRM-CERFACS-CNRM-CM5 & RCA4 & CNRM-CM5 \\
10 & SMHI.ICHEC-EC-EARTH & RCA4 & EC-EARTH \\
11 & SMHI.IPSL-IPSL-CM5A-MR & RCA4 & CM5A-MR \\
12 & SMHI.MOHC-HadGEM2-ES & RCA4 & HadGEM2-ES \\
13 & SMHI.MPI-M-MPI-ESM-LR & RCA4 & MPI-ESM-LR \\
14 & MPI-CSC.MPI-M-MPI-ESM-LR & REMO & MPI-ESM-LR \\
\hline
\end{tabular}

\section{Results}

The LCZ classification map at 400-m resolution (Figure 5) shows that the dominant morphological type of Athens is compact mid-rise (LCZ 2), covering almost completely the city center areas and a large part of the region around the central municipality. LCZ 2 also prevails at the central areas of Piraeus and can be further found in a few recently overbuilt suburban sites. The generally lower height of buildings at the western periphery of Athens results in a high coverage of the compact low-rise class (LCZ 3); whereas in the lower density districts-the northeastern and southeastern suburbs-the open mid-rise (LCZ 5) and open low-rise (LCZ 6) classes are prevalent. The extended large low-rise (LCZ 8) zone between the city centers of Athens and Piraeus was an active industrial center until the 1970s; nowadays, it serves as a light industrial site, including vacant buildings and brownfield land. The LCZ classification result for the central areas does not manage to describe potential microscale variations of differing surface energy balances, attributing them invariably to LCZ 2 . In addition, a clear distinction of the central commercial district of Athens cannot be made. This mainly stems from the historically imposed building height restrictions that result in the compact high-rise class (LCZ 1) (typically corresponding to downtown areas) to be absent from the 400-m scale mapping, with the exception of one pixel. Furthermore, areas of specific land use and associated thermal degradation (e.g., major highways) are not depicted. 


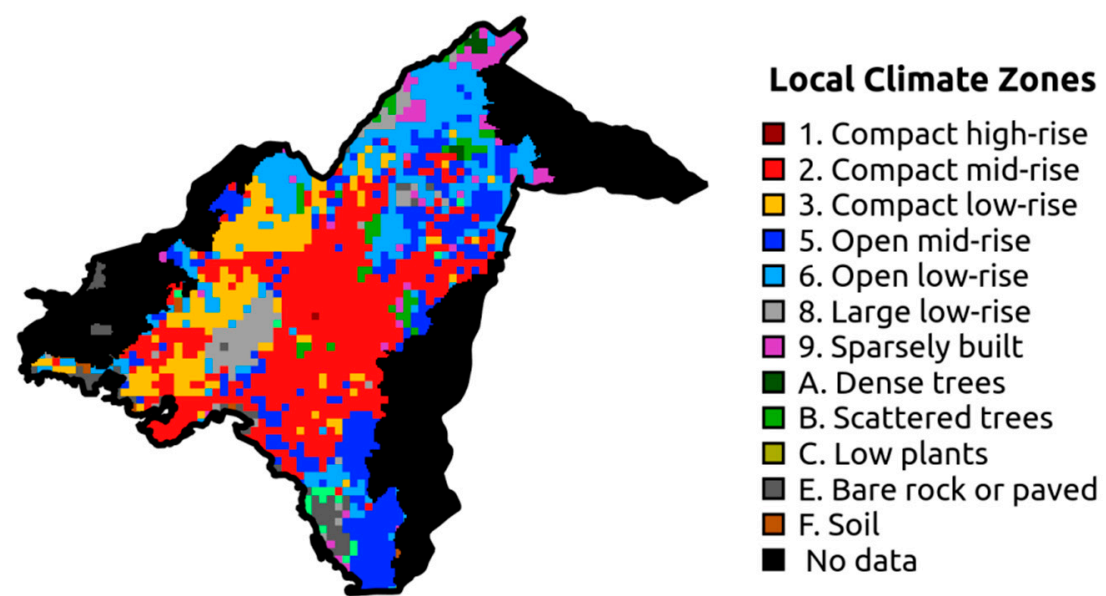

Figure 5. Spatial distribution of local climate zones (LCZs) for Athens at 400-meter resolution.

The H/W spatial distribution, as shown in Figure 6a, illustrates part of the previously unrevealed morphology of Athens. While high buildings (above $25 \mathrm{~m}$ ) are generally scarce, the excessive building density has resulted in disproportionately narrow roads, especially in the central city areas. As a consequence, a large percentage of urban canyons in the inner city of Athens are characterized by $\mathrm{H} / \mathrm{W}$ ratios over 2, while their adjacent buildings have a mean height fewer than $25 \mathrm{~m}$-which is a combination of morphological parameters that is not covered under the LCZ framework. For the outer urban districts, the $\mathrm{H} / \mathrm{W}$ patterns generally follow the $\mathrm{LCZ}$ classes, since $\mathrm{H} / \mathrm{W}$ is a primary threshold value in the LCZ mapping procedure. The lower H/W values tend to be found in the LCZ 8 class and in the sparsely built neighbourhoods (e.g., LCZ 9).

Figure $6 \mathrm{~b}$ presents the average $\beta_{\mathrm{m}}$ for July 2017 , as derived from daily downscaled MODIS-TERRA thermal data and synchronous meteorological measurements. The southwestern neighborhoods tend to have the higher magnitudes of $\beta_{\mathrm{m}}$ (i.e., channeling more heat into $Q_{H}$ than $Q_{E}$ ), which is readily associated with lower values of $\lambda_{\mathrm{v}}$ and high $T_{s}$. Significantly high midday Bowen ratio values (over 20) are estimated for the 100-meter resolution pixels that consist mainly of dry surfaces (rooftops, roads). Open impervious areas (LCZ 8 and LCZ E) are, as expected, also characterized by high $\beta_{\mathrm{m}}$ values. In contrast, the lower magnitude of $\beta_{\mathrm{m}}$ is generally seen in the more vegetated northern suburbs; $\beta_{\mathrm{m}}$ values as low as 0.6 can be found in a few northern residential districts, where $Q_{E}$ substantially exceeds $Q_{H}$ even at around midday. The central areas of Athens mainly tend to have high $\beta_{\mathrm{m}}$ (although lower in magnitude in comparison to those in the broader periphery of Piraeus) with the exception of urban parks, which have notably low values. The spatial variation of $\beta_{\mathrm{m}}$ is generally linked to $\lambda_{\mathrm{v}}$; however, wind speed, humidity, and aerodynamic properties play a contributing role in the developing patterns. 

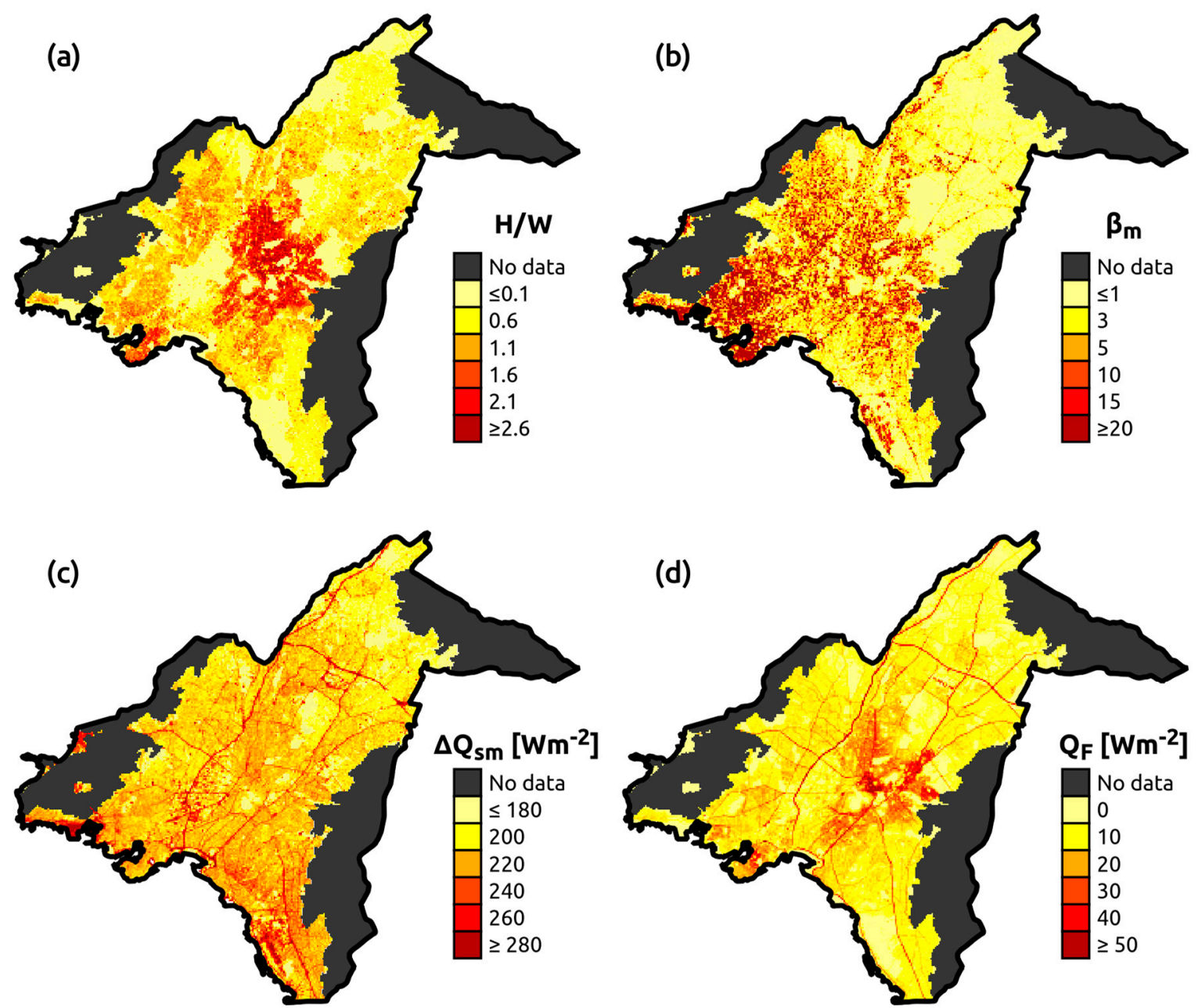

Figure 6. Spatial distribution at 100-meter resolution of: (a) the canyon aspect ratio $(\mathrm{H} / \mathrm{W})$, (b) the midday Bowen ratio $\left(\beta_{\mathrm{m}}\right)$ for July 2017, (c) the midday net storage heat flux $\left(\Delta \mathrm{Q}_{\mathrm{sm}}\right)$ for July 2017 , and (d) the mean daily anthropogenic heat flux $\left(Q_{F}\right)$ for July 2012.

The validation of the modeled $Q_{H}$ and $Q_{E}$ values was performed using the turbulent fluxes, which were calculated employing the EC method from the available flux tower measurements during July 2009. The $Q_{H}$ values estimated by the EC techniques ranged here from slightly positive nocturnal values to an average peak of $\sim 150 \mathrm{~W} \mathrm{~m}^{-2}$ at midday, which is in accordance with the results presented in [79]. In addition, relatively low $Q_{E}(\mathrm{EC})$ values were found, with a daily average maximum value of approximately $30 \mathrm{~W} \mathrm{~m}^{-2}$. For the detailed presentation and analysis of the measured energy and momentum fluxes at the Thermopolis campaign site, the reader is referred to the corresponding research papers $[79,87]$. To expand the synchronous remote sensing imagery and EC estimates availability in this study, along with the midday MODIS-TERRA, nighttime MODIS-TERRA ( 23:00 local time), and early afternoon MODIS-AQUA ( 15:00 local time), thermal images were used that were preprocessed as in [55] (imagery with a sensor viewing angle over $55^{\circ}$ were not included). Figure 7 shows that a moderate level of agreement is obtained between modeled (aerodynamic resistance method) and measured fluxes (EC method). An average root mean square error (RMSE) of $33.1 \mathrm{~W} \mathrm{~m}^{-2}$ was found for $Q_{H}$ and of $10.2 \mathrm{~W} \mathrm{~m}^{-2}$ for $Q_{E}$; when considering only daytime results, the RMSE was $41.5 \mathrm{~W} \mathrm{~m}^{-2}$ and $15.5 \mathrm{~W} \mathrm{~m}^{-2}$ for $Q_{H}$ and $Q_{E}$, respectively. A sensitivity analysis for the aerodynamic resistance methodology was conducted in order to investigate the response of the modeled turbulent fluxes to perturbations of the most significant input variables. The sensitivity of the different terms was individually tested, i.e., for each examined variable, all the other input values were held fixed; in addition, only the daytime fluxes were considered. As shown from Table 4 , the modeled $Q_{H}$ is highly 
sensitive to the $\left(T_{S}-T_{\alpha}\right)$ factor of Equation (1). A change of $2 \mathrm{~K}$ of the term results in a deviation of $\sim 20 \%$ for the estimated $Q_{H}$, which is an uncertainty of $\sim 30 \mathrm{~W} \mathrm{~m}^{-2}$ in the case of a sensible flux in the order of $150 \mathrm{~W} \mathrm{~m}^{-2}$. This highlights the high importance of acquiring accurate remotely sensed $T_{S}$ for the modeling of surface-atmosphere interactions. The downscaled $T_{S}$ used in this study was found to have an uncertainty of $\sim 1.5 \mathrm{~K}$ for the Thermopolis site and $<2 \mathrm{~K}$ for the entire study area [55]; thus, it is considered to have a relative large impact in the obtained errors. An additional important source of uncertainty in the remotely sensed turbulent fluxes is the derivation of the $u *$ value. Here, a smaller RMSE (by approximately $10 \mathrm{~W} \mathrm{~m}^{-2}$ ) was obtained for daytime results when the EC-derived $u$ * value was used in the place of the $u *$ value modeled from wind speed measurements. The respective change of the Bowen ratio from the perturbed $u *$ value is to an extent compensated, as both turbulent fluxes change in the same direction. $Q_{H}$ and $Q_{E}$ were found to be rather insensitive with perturbations in the aerodynamic parameters and the Obukhov length ( $<2 \%$ sensitivity). An additional source of uncertainty for $Q_{E}$ is the $\left(q_{s}-q\right)$ factor and the $r_{s m i n}$ parameter. Their impact in absolute terms is limited in the urban core, as $Q_{E}$ was found to have low values (fewer than $30 \mathrm{~W} \mathrm{~m}^{-2}$ ); however, for the vegetated suburbs, the estimation sensitivity is expected to be higher. The sensitivity analysis findings are in agreement with those reported in $[67,81]$ (in terms of percentage variations), where $T_{s}$ was also considered to be the most important parameter in the resulting sensitivity of the fluxes.
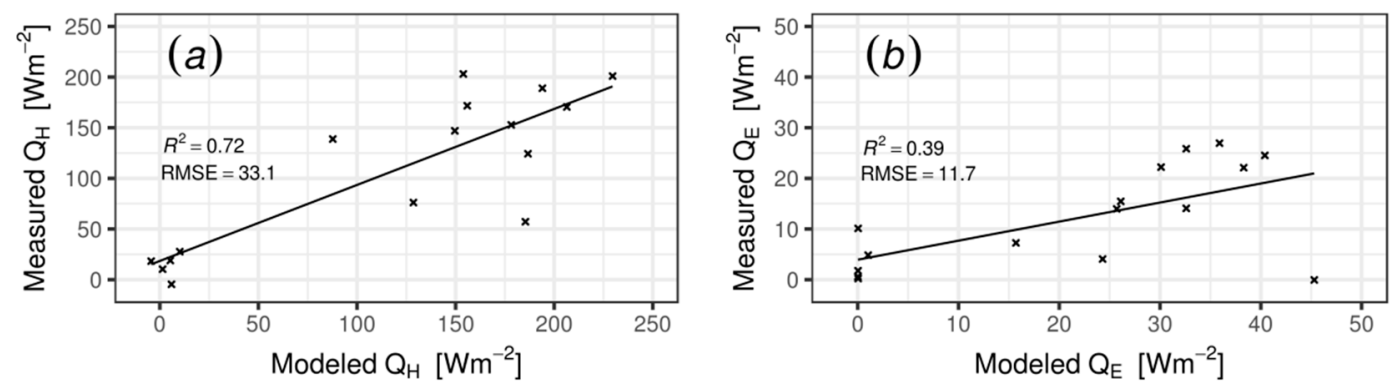

Figure 7. Comparison of modeled and measured turbulent fluxes: (a) $Q_{H}$ and (b) $Q_{E}$ for the available synchronous dates in July 2009.

A more uniform spatial distribution than $\mathrm{H} / \mathrm{W}$ and $\beta_{\mathrm{m}}$ was found for the estimated $\Delta \mathrm{Q}_{\mathrm{sm}}$ (Figure 6c). Generally, major highways and other open paved zones tend to be those with the larger values, which was a consequence of the lower surface reflectance and high OHM parameters for asphalt. A large $\Delta Q_{\mathrm{sm}}$ value is also obtained for central areas, due to the higher building density and lower vegetation fraction. Northern suburbs, which are covered to a large extent by natural surfaces, tend to absorb and store a smaller amount of heat. An average $\Delta \mathrm{Q}_{\mathrm{sm}}$ of $220 \mathrm{~W} \mathrm{~m}^{-2}$ at the Thermopolis flux tower site indicates that the OHM estimates are in good agreement with the average midday value of approximately $250 \mathrm{~W} \mathrm{~m}^{-2}$, which was derived as an energy balance residual during the Thermopolis campaign [87].

The average daily $Q_{F}$ value in Athens for July 2012 is presented in Figure 6d. It can be seen that a concentric pattern of heat emissions develops around the city center of Athens. Generally, the higher $Q_{F}$ values are associated with high commercial energy usage; the residential $Q_{F}$ value is relatively lower, despite the high population density and a continuous space cooling demand for the discussed period. Daily average $Q_{F}$ values up to $108 \mathrm{~W} \mathrm{~m}^{-2}$ were estimated for the commercial city center. The average $Q_{F}$ releases for residential areas do not exceed $60 \mathrm{~W} \mathrm{~m}^{-2}$, including the most densely built neighborhoods. Peak average heat emissions tend also to appear in the major highways, with values generally (up to $\sim 80 \mathrm{~W} \mathrm{~m}^{-2}$ ). A generally moderate $Q_{F T}$ can be found for the secondary traffic network, resulting from the contrasting features of Athens as a compact city with a well-established public transport network and with high vehicle ownership. The heat released by anthropogenic activities presented in Figure $6 \mathrm{~d}$ correspond to averaged values throughout daytime and nighttime hours. 
Table 4. Sensitivity analysis for the modeled turbulent fluxes and the derived Bowen ratio using the aerodynamic resistance methodology for July 2009. See text for symbol definitions.

\begin{tabular}{cccc}
\hline & $\left|\Delta Q_{H}\right|$ & $\left|\Delta Q_{\mathrm{E}}\right|$ & $|\Delta \beta|$ \\
\hline$\left(T_{S}-T_{\alpha}\right) \pm 2 \mathrm{~K}$ & $\sim 18.5 \%$ & - & $\sim 18.5 \%$ \\
$u_{*} \pm 10 \%$ & $\sim 7.5 \%$ & $\sim 2 \%$ & $\sim 5.5 \%$ \\
$\mathrm{z}_{0} \pm 10 \%$ & $\sim 1 \%$ & $\sim 0.5 \%$ & $\sim 1 \%$ \\
$\mathrm{z}_{\mathrm{d}} \pm 10 \%$ & $\sim 2.5 \%$ & $\sim 1 \%$ & $\sim 2 \%$ \\
$\left(q_{s}-\mathrm{q}\right) \pm 10 \%$ & - & $\sim 10 \%$ & $\sim 10 \%$ \\
$r_{\text {smin }} \pm 10 \%$ & - & $\sim 7 \%$ & $\sim 7 \%$ \\
$\mathrm{~L} \pm 10 \%$ & $\sim 1 \%$ & $\sim 0.5 \%$ & $\sim 1 \%$ \\
\hline
\end{tabular}

In order to outline the daily $Q_{F}$ dynamics and the local spatial variations, the median daily temporal profiles of $Q_{F}$ (for July 2012) are calculated for an extended area $\left(\sim 530,000 \mathrm{~m}^{2}\right)$ covering the city center of Athens ("Athens Commercial Triangle") (Site 01 in Figure 8) and five representative grid cells $\left(10,000 \mathrm{~m}^{2}\right)$ corresponding: (i) to an anthropogenic emissions hot spot inside the above-mentioned area (located in the vicinity of the Omonoia Square), (ii) the Thermopolis flux tower site (Patission Street), (iii) a main traffic corridor site (Kifissou Avenue), (iv) a high population density residential site (Zografou), and (v) a low population density residential site (Vrilissia) (sites 02-06 in Figure 8). For the city center (Figure 9a), it can be seen that $Q_{F}$ follows a bell-shaped curve profile with high values between (9:00-17:00), corresponding to the combined effect of heat emissions from air conditioning usage, vehicular traffic, and the various office/shop electricity needs. A late evening increase reflects increased $Q_{F}$ values from recreational venues in the examined area. The average daytime heat emissions for the Athens Commercial Triangle are about $75 \mathrm{~W} \mathrm{~m}^{-2}$, with a peak value over $100 \mathrm{~W} \mathrm{~m}^{-2}$. The local commercial site presented in Figure $9 \mathrm{~b}$ follows a similar daily cycle; however, it is characterized by much higher anthropogenic heat releases with average daytime $Q_{F}$ values of $125 \mathrm{~W} \mathrm{~m}^{-2}$ and a maximum of $170 \mathrm{~W} \mathrm{~m}^{-2}$. The peak surpassed $185 \mathrm{~W} \mathrm{~m}^{-2}$ in the hottest day of the month. With increasing distance from the city center core, the anthropogenic emissions are becoming lower in magnitude (Figure 9c). For Patission Street (Thermopolis site), an estimation for $Q_{F}$ of approximately $50 \mathrm{~W} \mathrm{~m}^{-2}$ has been previously derived in [79] — for a coincident period under similar meteorological conditions (July 2009) — using the assumption that during the daylight hours, anthropogenic heat emissions are included in the sum of turbulent fluxes and upwelling longwave radiation, and subsequently employing a fluxes time lag between normal working days and Sunday. Despite the differences in methodologies in [79] and in this study, a reasonable level of agreement is found, with estimated daytime values of $\sim 40 \mathrm{~W} \mathrm{~m}^{-2}$ (Figure 9c). The temporal profile shown in this figure presents differences from the profile in Figure 9a, due to the stronger relative contributions of vehicular, residential, and metabolic emissions in the area compared to the commercial buildings' $Q_{F}$ component. The daily evolution of $Q_{F}$ is also significantly different for the Kifissou Avenue site (Figure 9d); the two daily maxima correspond to morning/evening traffic rush hours. During these high vehicular traffic moments, $Q_{F}$ reaches up to $100 \mathrm{~W} \mathrm{~m}^{-2}$, whereas heat emissions during the nighttime get closer to zero. The primarily residential site of Figure 9e shows higher evening $Q_{F}$ values, reflecting the hours that most people spend at home, rather than at their workplace. The average daytime anthropogenic heat flux is $56 \mathrm{~W} \mathrm{~m}^{-2}$, while an absolute maximum for the month was found to be over $75 \mathrm{~W} \mathrm{~m}^{-2}$. In the early nighttime hours, a relative high $Q_{F}$ value is sustained as a result of space-cooling energy usage. Finally, in the low-density residential site (Figure 9f), anthropogenic heat emissions are significantly lower, and daytime variations are relatively small. 


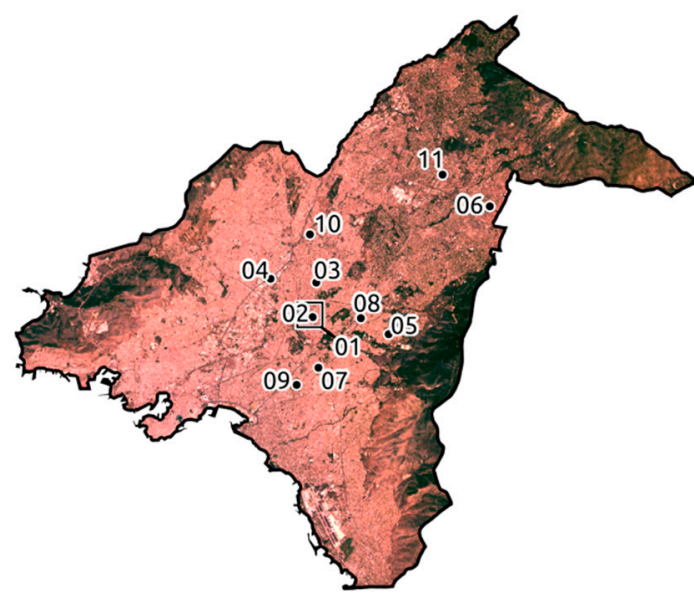

01: City center

02: Omonoia square

03: Thermopolis site

04: Kifissou Avenue

05: Zografou

06: Vrilissia

07: Neos Kosmos

08: Ampelokipoi

09: Nea Smyrni

10: Patissia

11: Maroussi

Figure 8. Location map of specific study sites within the urban area of Athens. Base map: Landsat 8 true colour (red-green-blue, RGB) composite image (overpass: 28 June 2017).
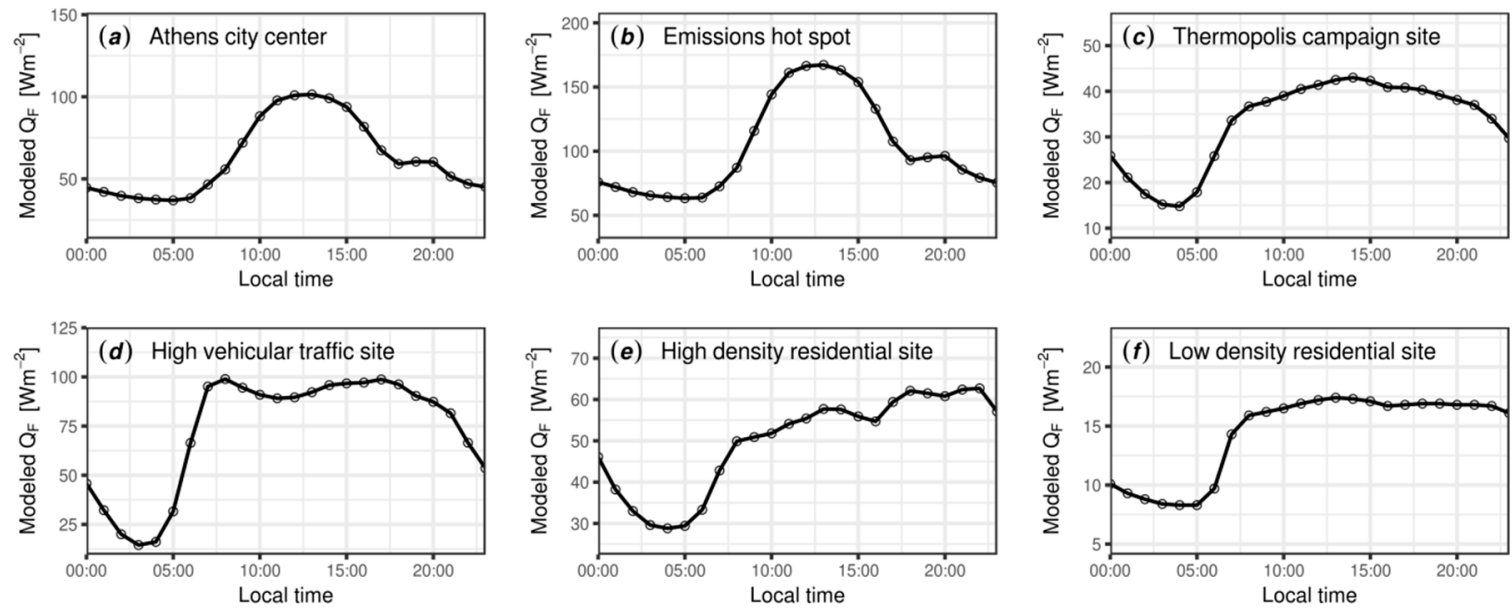

Figure 9. Temporal profiles of the median hourly total $Q_{F}$ for July 2012 for six selected sites in the study area: (a) the city center (Athens Commercial Triangle), (b) a commercial site of peak emissions (Omonoia Square), (c) the site of the Thermopolis campaign (Patission Street), (d) a high-traffic site (Kifissou Avenue), (e) a typical high-density residential site (Zografou), and (f) a typical low-density residential site (Vrilissia). Note that the $Q_{F}$ y-axis differs among graphs.

In Figure 10, the annual variations of citywide total $Q_{F}$ and of its individual components are presented, relative to the built-up land area (as outlined in Figure 1). The citywide aggregated $Q_{F}$ values vary from 7.8 to $29.6 \mathrm{~W} \mathrm{~m}^{-2}$, with an average value of $13.9 \mathrm{~W} \mathrm{~m}^{-2}\left(9 \mathrm{~W} \mathrm{~m}^{-2}\right.$ when the total land area is considered), including both daylight and nocturnal emissions. The seasonal cycles of $Q_{F B}$ (electricity and oil/gas) were well reproduced (Figure 10) following the varying heating and cooling demands; interestingly, $Q_{F B}$ for the cold period is vastly higher in comparison to the summer months. This finding is consistent with a recent energy consumption survey for Greek households (ELSTAT) [129] and can be attributed to the poor construction standards and lack of insulation for a large proportion of buildings in Athens, a potential relative higher tolerance of the population to warmer than colder conditions, and furthermore, the lower number of city dwellers in July and August, as a result of summer holidays. 


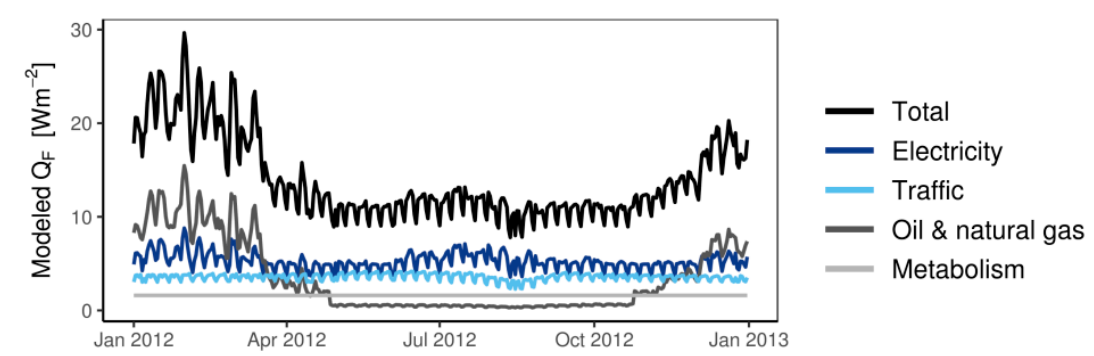

Figure 10. Annual variation of total $Q_{F}$ and individual $Q_{F}$ components in the Athens agglomeration (average city-scale magnitude for the built-up area of Figure 1) for 2012.

Then, PCA was applied to the images of the four examined thermal parameters $\left(H / W, \beta_{\mathrm{m}}, \Delta \mathrm{Q}_{\mathrm{sm}}\right.$, and $Q_{F}$ ) (Figure 6); the obtained results of the analysis are shown in Table 5 and Figure 11. As can be observed, the first principal component (PC1) integrates a large amount of the spatial variation that characterizes the initial, individual variables (50.6\%). Critically, PC1 is accompanied with positive component coefficients (scores) for all the parameters. Thus, it can be regarded as the composite image for which the pixel values correspond to the aggregated thermal effect of the heat-related parameters, while preserving the maximum possible proportion of the total variance in the original dataset. The degree of variation that is not feasible to be accounted through PC1 is to a significant extent expected, as the urban climate may be viewed as the mix of different thermal effects that often exhibit contrasting results. For instance, high $\mathrm{H} / \mathrm{W}$ values-which are in general associated with higher thermal stress-may result in lower midday $T_{s}$ values due to the shading of the buildings and the canopy surface. PC2 contains a considerable amount of variance (23.7\%); however, it can be directly linked to more specific cases areas that can be distinguished from a microclimatic point of view. Specifically, PC2 is mainly associated with regions characterized by the contrasting combination of high $\Delta \mathrm{Q}_{\text {sm }}$ estimates and low $\mathrm{H} / \mathrm{W}$ values, as it can be inferred from the high values and opposite signs of component scores for the two parameters in Table 5 and from the patterns in Figure 11b. This situation coincides with city areas of high impervious ground fraction $\left(\lambda_{\mathrm{i}}\right)$ (primarily light industrial and port areas) that tend to have lower reflectance and high OHM coefficients (see Table 1). In addition, PC2 is considered to be directly affected by a limitation of the OHM scheme, which tends to overestimate the net heat storage from impervious ground surfaces in comparison with high-rise buildings configurations [130]. Finally, the strong heat storage release in the PC2 hot spots is expected to have less influence on the UHI intensity, as low $\mathrm{H} / \mathrm{W}$ values will result in higher cooling rates. Likewise, as indicated from Table 5 and Figure 11, PC3 and PC4 correspond to particular cases of high $\beta_{\mathrm{m}}$ and $Q_{F}$ estimates. However, the amount of explained variance for these components is lower, and furthermore, the corresponding parameters have already been, to a great extent, incorporated in PC1.

Considering the above, it was determined to associate UHeatEx only with the first principal component (PC1). This decision is further justified considering that employing a different weighting technique-e.g., equal weights or assignment of weights through expert opinion-would lead to even lower explained variance, since PC1 corresponds by definition to the linear combination that accounts for the largest amount of variability. Nevertheless, in case where there is differentiation with respect to the sign of component scores for PC1, either both PC1 and PC2 should be regarded as UHeatEx, or an alternative weighting procedure may be followed for the four components $(\mathrm{H} / \mathrm{W}$, $\beta_{\mathrm{m}}, \Delta \mathrm{Q}_{\mathrm{sm}}$, and $\left.Q_{F}\right)$. Furthermore, as UHeatEx is a physically based indicator, it is suggested that these four initial parameters should be presented alongside the indicator. In this way, the distinct features of the urban form and function can be identified for different regions, thus enabling the identification of tailor-made climate adaptation responses. The final results for UHeatEx-after being normalized to a 0 to 10 scale-are presented in Figure 12. As stated above, all the heat-related parameters exhibit positive scores for PC1 (and correspondingly UHeatEx); therefore, the scale of Figure 12 can be regarded as classes of Very Low/Low (0-4), Moderate (4-6), and High/Very High (6-10) heat exposure. The spatial distribution of UHeatEx illustrates the diversity of Athens microclimates 
and surface energy balance modifications. The higher UHeatEx values are found in the city center of Athens, where all the driving forces of excess urban heat have high magnitudes, in particular $\mathrm{H} / \mathrm{W}$ and $Q_{F}$. Low thermal environmental quality is also estimated for a secondary pole of high commercial concentration northeast of the city central area, for the overbuilt residential districts at the central municipality, the city center of Piraeus, and the southwestern districts. The busiest highways are also clearly outlined, following extensive vehicular heat emissions and distinct surface cover characteristics. Northern and southeastern suburbs tend to have the lowest UHeatEx values; low magnitudes are also found in the light industrial zone, reflecting its stronger surface cooling potential, due to a high sky view factor.

Table 5. Results of the principal components (PC) coefficients.

\begin{tabular}{ccccc}
\hline Principal Components $^{1}$ & $\mathbf{H} / \mathbf{W}$ & $\boldsymbol{\beta}_{\mathrm{m}}$ & $\boldsymbol{\Delta} \mathbf{Q}_{\text {sm }}$ & $\boldsymbol{Q}_{\boldsymbol{F}}$ \\
\hline PC1 & 0.524 & 0.476 & 0.381 & 0.594 \\
PC2 & -0.559 & 0.275 & 0.753 & -0.210 \\
PC3 & -0.082 & 0.834 & -0.451 & -0.305 \\
PC4 & -0.637 & 0.042 & -0.289 & 0.713 \\
\hline
\end{tabular}

${ }^{1}$ Percentage of explained total variance: $\mathrm{PC} 1=50.6 \%, \mathrm{PC} 2=23.7 \%, \mathrm{PC} 3=16.8 \%, \mathrm{PC} 4=8.7 \%$.
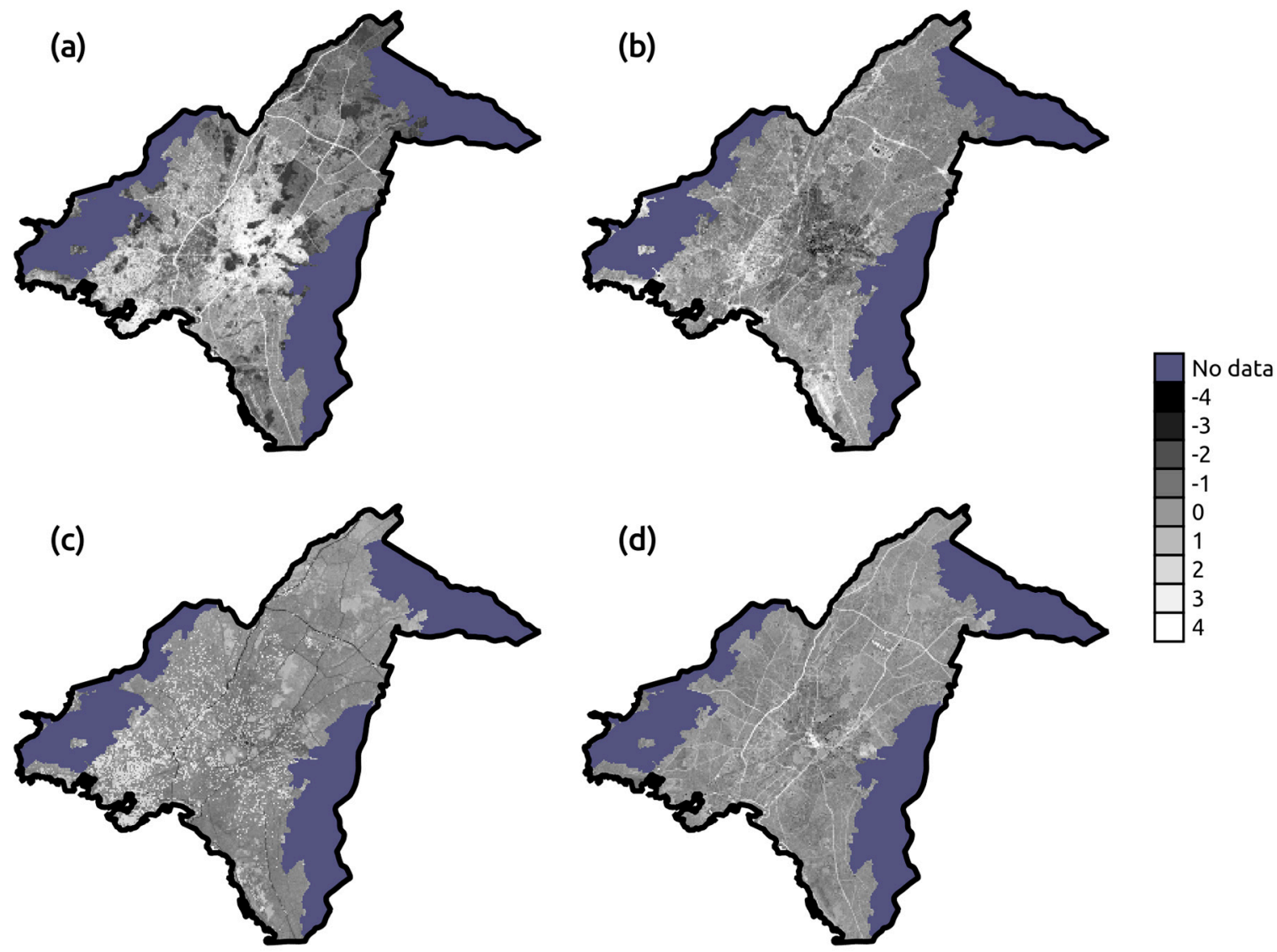

Figure 11. Results of the principal components (PC) analysis: (a) PC1, (b) PC2, (c) PC3, and (d) PC4. 


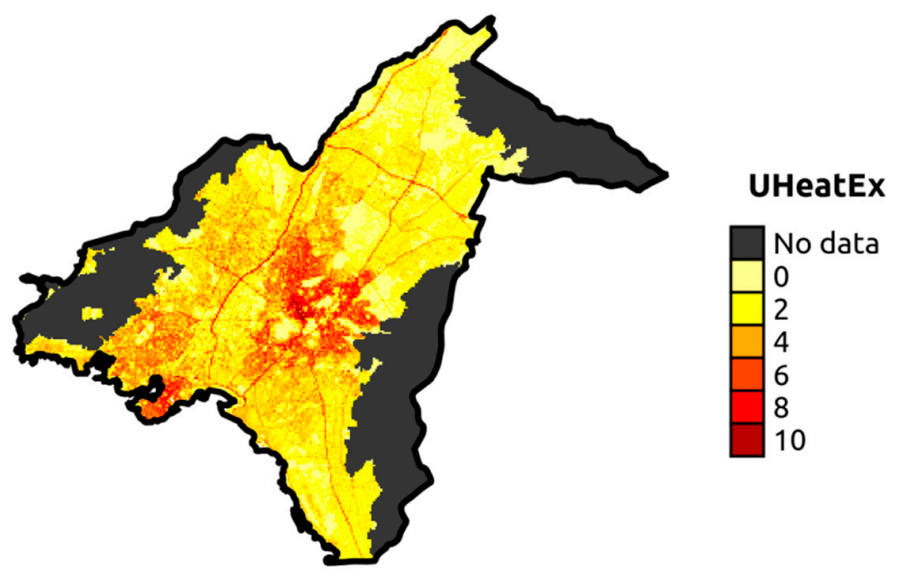

Figure 12. Spatial distribution of the UHeatEx indicator for Athens at 100-meter resolution; scale varying from low (0) to high (10) thermal environmental quality.

The average minimum $T_{\alpha}\left(T_{\alpha \min }\right)$ during the warm period (May-September) for the years 2013 to 2018 was calculated for five weather stations in the central neighborhoods of Athens (sites 07-11 in Figure 8). All the station sites correspond to the LCZ 2 class (both at 100-m and at 400-m scale); however, they differ in the derived UHeatEx scores. $T_{\alpha \min }$ was selected to be examined, as $\mathrm{UHI}_{\mathrm{UCL}}$ is predominantly a nocturnal phenomenon $[43,131]$ due to slower cooling rates for the denser urban areas. Since long-term canopy layer temperatures for the study area were not available, measurements in the RSL were used (Section 2.3), corresponding to a combined effect of microscale and local-scale processes [89]. The results presented in Table 6 indicate that UHeatEx values follow the $T_{\text {amin }}$ measurements well, reflecting both the stored warmth during the day and the subsequent nighttime release. Especially for the northern station (Site 11), the higher amount of green space and the associated cooling effects led to significantly lower temperatures; while it belonging to the morphological type of densely built LCZs.

Table 6. Comparison of the average minimum air temperature $\left(T_{\alpha \min }\right)$ at five compact mid-rise (LCZ 2) sites in Athens, for 2013-2018 (May-September). Site ID refers to site codes of Figure 8.

\begin{tabular}{cccccc}
\hline Name & Site ID & Location $(\mathbf{W}, \mathbf{N})$ & Elevation $(\mathbf{m})$ & UHeatEx & $T_{\boldsymbol{\alpha m i n}}\left({ }^{\circ} \mathbf{C}\right)$ \\
\hline Neos Kosmos & 07 & $23^{\circ} 43^{\prime} 57^{\prime \prime}, 37^{\circ} 57^{\prime} 32^{\prime \prime}$ & 85 & 6.3 & 23.2 \\
Ampelokipoi & 08 & $23^{\circ} 45^{\prime} 30^{\prime \prime}, 37^{\circ} 58^{\prime} 54^{\prime \prime}$ & 136 & 5.5 & 22.5 \\
Nea Smyrni & 09 & $23^{\circ} 43^{\prime} 10^{\prime \prime}, 37^{\circ} 57^{\prime} 5^{\prime \prime}$ & 51 & 4.0 & 23.0 \\
Patissia & 10 & $23^{\circ} 43^{\prime} 47^{\prime \prime}, 38^{\circ} 1^{\prime} 19^{\prime \prime}$ & 90 & 3.4 & 22.3 \\
Maroussi & 11 & $23^{\circ} 48^{\prime} 36^{\prime \prime}, 38^{\circ} 2^{\prime} 54^{\prime \prime}$ & 235 & 2.6 & 20.9 \\
\hline
\end{tabular}

UHeatEx demonstrates that the urban thermal landscape of Athens is characterized by a high spatial variability, both among different districts and for nearby urban blocks. At first sight, this thermal inequity seems to be associated with the socioeconomic status of residents. Low UHeatEx values are found in the affluent north and southeastern areas and high values are found in the lower-income and medium-income west and central areas. A more clear view can be obtained by examining the relationship between the mean household income per postal code for year 2011 (Greek Ministry of Finance; http://www.gsis.gr/gsis/info/gsis_site/PublicIssue/) and the corresponding average UHeatEx values (non-residential land use zones were excluded from consideration). From Figure 13, it follows that a correlation is present between household income and UHeatEx $\left(R^{2}=0.45\right)$, albeit moderate in strength; a significant spread of the indicator values is found for medium incomes, with higher UHeatEx for the areas of central Athens.

Climate change is expected to augment the impacts of the current urban overheating. As follows from Figure 14, a positive trend of $0.24{ }^{\circ} \mathrm{C}$ per decade for the annual mean temperature and of $0.28{ }^{\circ} \mathrm{C}$ 
per decade for the mean temperature of summer months was found to be projected for the next 50 years in Athens, according to the multi-model mean of the EURO-CORDEX simulations.

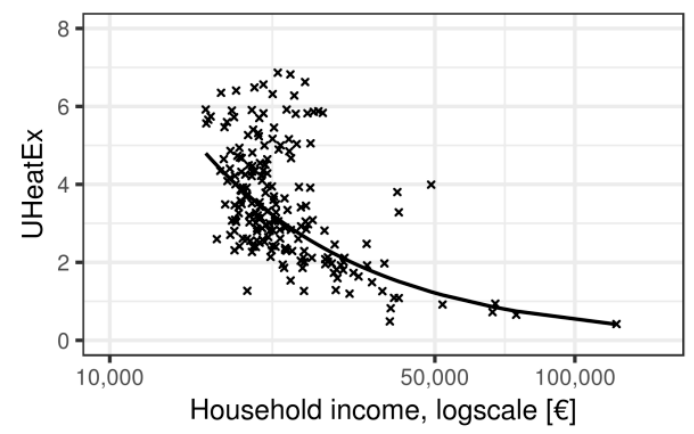

Figure 13. The relationship between the household income and the UHeatEx indicator per postal code in Athens.

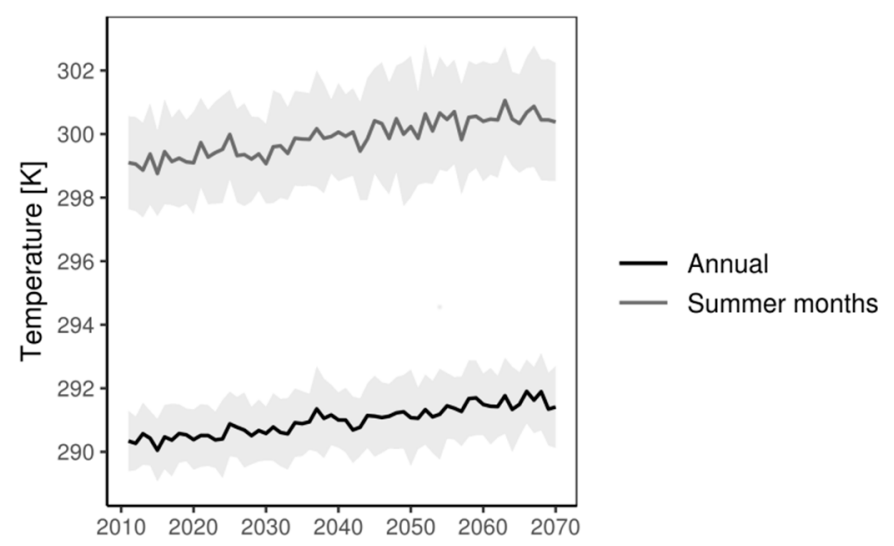

Figure 14. Projected near-surface air temperatures for Athens, using the multi-model mean of the EURO-CORDEX ensemble simulations for 2020-2070; shading indicates \pm 1 standard deviation.

\section{Discussion}

City planners and policy makers need to consider the local-scale vulnerability in climate change adaptation actions. UHeatEx provides a map-based planning tool that can help the identification of the most sensitive urban climatic areas across a city. Furthermore, the physical basis of the indicator-integrating the urban form, function, and surface energy exchanges-can assist planners in deciding appropriate, site-specific actions that can improve the urban thermal environment. Generally, UHeatEx (Figure 12) better presents the urban inner spatial heterogeneity of Athens compared to the LCZ mapping (Figure 5) -it highlights the city-specific characteristics of urban form and allows a physical explanation of the derived values. This was also demonstrated by examining the $T_{\alpha m i n}$ of five LCZ 2 stations (Table 6); UHeatEx managed, to a great extent, to match the thermal variability of these cases. Further validation of the indicator is planned for future research, focusing on $T_{\alpha}$ measurements inside the UCL.

In the literature, several studies have modeled the urban energy fluxes using a remotely-sensed approach [66-68,132-138]; however, only few of them made synchronous measurements of the turbulent fluxes available for validation purposes. Here, the obtained accuracy is considered to be consistent with the reported errors in recent studies of long-term, remotely-sensed turbulent fluxes $[68,81,86]$. Furthermore, the present work extends the current knowledge of the applicability of the downscaled satellite $T_{S}$ in the urban $Q_{H}$ estimation, which to the authors' knowledge has only be examined in [68]. Downscaled thermal data are necessary in the estimation of high-resolution daily fluxes, due to the trade-off between spatial and temporal resolutions of current thermal imagery [139]. 
High anthropogenic heat emissions were obtained for the city center of Athens $\left(\sim 100 \mathrm{~W} \mathrm{~m}^{-2}\right.$ at summer midday, with local peaks up to $185 \mathrm{~W} \mathrm{~m}^{-2}$ ) and the major highways. On the other hand, the average $Q_{F}$ for the greater urban area of the city was considerably lower (city-scale average magnitude under $30 \mathrm{~W} \mathrm{~m}^{-2}$ for all dates), which was mostly due to the reduced anthropogenic heat emissions in areas that were at a great distance from the city center. These findings confirm the importance of scale in the anthropogenic heat emissions estimation [97,98] and follow the general premise of [140], which concludes that values in the central city areas can be up to 5-10 times higher than the citywide values. A typical example of the $Q_{F}$ scale and temporal dependence is the case of the city Tokyo, where in [141], a significantly high daytime anthropogenic heat flux value-over $400 \mathrm{~W} \mathrm{~m}^{-2}$ —was derived on several $25 \mathrm{~m} \times 25 \mathrm{~m}$ grid cells in central areas, whereas for the greater Tokyo urban area, average $Q_{F}$ values in the range of 20 to $40 \mathrm{~W} \mathrm{~m}^{-2}$ were later estimated [99,142]. The relatively low average city-scale anthropogenic flux that was found in this study for Athens (annual average of $14 \mathrm{~W} \mathrm{~m}^{-2}$ ) is in agreement with reported $Q_{F}$ aggregates for a few metropolitan areas worldwide: for instance, $13.2 \mathrm{~W} \mathrm{~m}^{-2}$ in Istanbul [118], $10.9 \mathrm{~W} \mathrm{~m}^{-2}$ for London [103], $6.2 \mathrm{~W} \mathrm{~m}^{-2}$ in Manchester [102], and $16.8 \mathrm{~W} \mathrm{~m}^{-2}$ in Mexico City [118].

As shown from Figure 13, UHeatEx displayed a moderate correlation with household income. The distribution of the indicator can be interpreted by considering the main aspects of post-war urban development and spatial socioeconomic segregation in Athens. In the 1950s-1970s, the at the time affluent center was massively built through a flats-for-land system [143] that led to the unregulated replacement of low-rise housing stock with multi-story apartments [144] for relative narrow streets-i.e., forming urban canyons of high $\mathrm{H} / \mathrm{W}$. The working class dwelled in lower height, often initially informal, settlements at the western periphery of the agglomeration $[145,146]$. As a result, these western areas, especially in the northwestern districts, have lower building density, $\mathrm{H} / \mathrm{W}$, and anthropogenic heat emissions $\left(Q_{F}\right)$. The deterioration of living conditions in the central areas due to overbuilding -including overheating, as demonstrated by UHeatEx-led to a portion of the middle and higher social classes gradually relocating to the vegetated northern and southeastern suburbs [147], with the exception of the residents of some historically important central neighborhoods. In the 1990s, the majority of the arriving immigrants settled around the city center, where they mixed with the remaining lower and middle-class residents [48]. Considering the above, it follows that the east-west social segregation of Athens $[148,149]$ is less pronounced in terms of unequally distributed extra warmth; however, an income-based stratification of the thermal environmental quality is generally present in the agglomeration. The synergy of the UHI and the global climate change (Figure 14) will further exacerbate the existing overheating hazards in Athens. Increased energy for cooling is expected to outweigh the decreased heating consumption for Greece $[150,151]$ and exert additional stress on current UHI health implications in Athens [152].

\section{Conclusions}

In this study, a new approach for the development of urban thermal indicators was followed, proposing a physical-based composite indicator (UHeatEx). Four parameters representing the predominant driving forces of the UHI $\left(\mathrm{H} / \mathrm{W}, \beta=Q_{H} / Q_{E}, \Delta \mathrm{Q}_{\mathrm{s}}\right.$, and $\left.Q_{F}\right)$ were calculated using Earth observation and GIS techniques, in conjunction with meteorological and authoritative data; these individual components were subsequently integrated via PCA to UHeatEx. The central areas of Athens were found to be characterized by particularly high $\mathrm{H} / \mathrm{W}$ values (often larger than 2.5), arising mainly from the exceptionally narrow canyons of the area. The partitioning between the turbulent fluxes (i.e., the parameter $\beta$ ) was observed to exhibit large spatial variation; $Q_{E}$ was significantly limited by low vegetation fraction in the southwestern suburbs, resulting in midday Bowen ratio estimates over 20. Downscaled remotely sensed surface temperatures demonstrated an overall adequate performance in the calculation of the turbulent fluxes, although existing uncertainties require further future investigation. The anthropogenic heat emissions proved to a large extent to be a localized phenomenon. The aggregated $Q_{F}$ values for the total urban area were relative low; however, 
considerably anthropogenic heat releases were estimated for the city center of Athens $\left(Q_{F}\right.$ surpassing $100 \mathrm{~W} \mathrm{~m}^{-2}$ in summer months) and the major highways of the region. UHeatEx successfully described the heterogeneous thermal landscape of Athens, better reflecting the city-specific characteristics and heat-stress challenges in comparison to the LCZ scheme. Athens was found to be characterized by a large variability in terms of vulnerability to UHI and climate change. This uneven distribution of overheating was demonstrated to have a moderate correlation to social differentiation and be a product of the urban development practices of previous decades. UHeatEx can be an essential component of current sustainable urban planning, since it considers the city as a three-dimensional dynamic system, in interaction with human activities under a warming climate.

Author Contributions: All the authors conceived and designed the study. I.A. performed the implementation of the methodology, including the validation of results and the preparation of the figures. All the authors contributed to the interpretation of the results and the writing of the manuscript.

Funding: This research is co-financed by Greece and the European Union (European Social Fund- ESF)through the Operational Programme «Human Resources Development, Education and Lifelong Learning» in the context of the project "Strengthening Human Resources Research Potential via Doctorate Research" (MIS-5000432), implemented by the State Scholarships Foundation (IK $\Upsilon$ ).

Acknowledgments: The authors are thankful to the Hellenic Cadastre for providing the digital elevation models, to the Hellenic Statistical Authority for the cartographic data, to the Hellenic Electricity Distribution Network Operator for the electricity consumption data, to the Athens Traffic Management Centre for the road traffic data, and to the European Space Agency for providing access to the Thermopolis 2009 Campaign dataset. The National Observatory of Athens is acknowledged for proving online access to the meteorological data. Thanks are due to Nektarios Chrysoulakis for offering helpful advice on the early stages of the manuscript.

Conflicts of Interest: The authors declare no conflict of interest.

\section{References}

1. United Nations. Press Release of the World Urbanization Prospects 2018; United Nations: New York, NY, USA, 2018.

2. Oke, T.R. The energetic basis of the urban heat island. Q. J. R. Meteorol. Soc. 1982, 108, 1-24. [CrossRef]

3. Oke, T.R.; Mills, G.; Christen, A.; Voogt, J.A. Urban Climates; Cambridge University Press: Cambridge, UK, 2017.

4. Fortuniak, K.; Kłysik, K.; Wibig, J. Urban-rural contrasts of meteorological parameters in Łódź. Theor. Appl. Climatol. 2006, 84, 91-101. [CrossRef]

5. Van Hove, L.W.A.; Jacobs, C.M.J.; Heusinkveld, B.G.; Elbers, J.A.; van Driel, B.L.; Holtslag, A.A.M. Temporal and spatial variability of urban heat island and thermal comfort within the Rotterdam agglomeration. Build. Environ. 2015, 83, 91-103. [CrossRef]

6. Skarbit, N.; Stewart, I.D.; Unger, J.; Gál, T. Employing an urban meteorological network to monitor air temperature conditions in the 'local climate zones' of Szeged, Hungary. Int. J. Climatol. 2017, 37, 582-596. [CrossRef]

7. Keramitsoglou, I.; Kiranoudis, C.T.; Ceriola, G.; Weng, Q.; Rajasekar, U. Identification and analysis of urban surface temperature patterns in Greater Athens, Greece, using MODIS imagery. Remote Sens. Environ. 2011, 115, 3080-3090. [CrossRef]

8. Parlow, E.; Vogt, R.; Feigenwinter, C. The urban heat island of Basel-Seen from different perspectives. Die Erde J. Geogr. Soc. Berl. 2014, 145, 96-110.

9. Bonafoni, S.; Anniballe, R.; Pichierri, M. Comparison between surface and canopy layer urban heat island using MODIS data. In Proceedings of the 2015 Joint Urban Remote Sensing Event (JURSE), Lausanne, Switzerland, 30 March-1 April 2015; pp. 1-4.

10. Santamouris, M.; Cartalis, C.; Synnefa, A.; Kolokotsa, D. On the impact of urban heat island and global warming on the power demand and electricity consumption of buildings-A review. Energy Build. 2015, 98, 119-124. [CrossRef]

11. Magli, S.; Lodi, C.; Lombroso, L.; Muscio, A.; Teggi, S. Analysis of the urban heat island effects on building energy consumption. Int. J. Energy Environ. Eng. 2015, 6, 91-99. [CrossRef]

12. Zanobetti, A.; Schwartz, J. Temperature and mortality in nine US cities. Epidemiology 2008, 19, 563-570. [CrossRef] 
13. Pyrgou, A.; Santamouris, M. Increasing probability of heat-related mortality in a Mediterranean city due to urban warming. Int. J. Environ. Res. Public Health 2018, 15, 1571. [CrossRef]

14. Nastos, P.T.; Matzarakis, A. The effect of air temperature and human thermal indices on mortality in Athens, Greece. Theor. Appl. Climatol. 2012, 108, 591-599. [CrossRef]

15. Heaviside, C.; Tsangari, H.; Paschalidou, A.; Vardoulakis, S.; Kassomenos, P.; Georgiou, K.E.; Yamasaki, E.N. Heat-related mortality in Cyprus for current and future climate scenarios. Sci. Total Environ. 2016, 569-570, 627-633. [CrossRef] [PubMed]

16. Fouillet, A.; Rey, G.; Laurent, F.; Pavillon, G.; Bellec, S.; Guihenneuc-Jouyaux, C.; Clavel, J.; Jougla, E.; Hémon, D. Excess mortality related to the August 2003 heat wave in France. Int. Arch. Occup. Environ. Health 2006, 80, 16-24. [CrossRef] [PubMed]

17. Kosatsky, T.; Henderson, S.B.; Pollock, S.L. Shifts in Mortality during a Hot Weather Event in Vancouver, British Columbia: Rapid Assessment with Case-Only Analysis. Am. J. Public Health 2012, 102, 2367-2371. [CrossRef] [PubMed]

18. Stocker, T. Climate Change 2013: The Physical Science Basis: Working Group I Contribution to the Fifth Assessment Report of the Intergovernmental Panel on Climate Change; Cambridge University Press: Cambridge, UK, 2014.

19. Rosenzweig, C.; Solecki, W.D.; Hammer, S.A.; Mehrotra, S. Climate Change and Cities: First Assessment Report of the Urban Climate Change Research Network; Cambridge University Press: Cambridge, UK, 2011.

20. Shonkoff, S.B.; Morello-Frosch, R.; Pastor, M.; Sadd, J. The climate gap: Environmental health and equity implications of climate change and mitigation policies in California-A review of the literature. Clim. Chang. 2011, 109, 485-503. [CrossRef]

21. Grineski, S.E.; Collins, T.W.; Ford, P.; Fitzgerald, R.; Aldouri, R.; Velázquez-Angulo, G.; de Lourdes Romo Aguilar, M.; Lu, D. Climate change and environmental injustice in a bi-national context. Appl. Geogr. 2012, 33, 25-35. [CrossRef]

22. Mitchell, B.C.; Chakraborty, J. Landscapes of thermal inequity: Disproportionate exposure to urban heat in the three largest US cities. Environ. Res. Lett. 2015, 10, 115005. [CrossRef]

23. Voelkel, J.; Hellman, D.; Sakuma, R.; Shandas, V. Assessing Vulnerability to Urban Heat: A Study of Disproportionate Heat Exposure and Access to Refuge by Socio-Demographic Status in Portland, Oregon. Int. J. Environ. Res. Public Health 2018, 15, 640. [CrossRef]

24. Ren, C.; Lau, K.L.; Yiu, K.P.; Ng, E. The application of urban climatic mapping to the urban planning of high-density cities: The case of Kaohsiung, Taiwan. Cities 2013, 31, 1-16. [CrossRef]

25. Stewart, I.D.; Oke, T.R. Local Climate Zones for Urban Temperature Studies. Bull. Am. Meteorol. Soc. 2012, 93, 1879-1900. [CrossRef]

26. Alexander, P.J.; Mills, G. Local Climate Classification and Dublin's Urban Heat Island. Atmosphere 2014, 5, 755-774. [CrossRef]

27. Arnds, D.; Böhner, J.; Bechtel, B. Spatio-temporal variance and meteorological drivers of the urban heat island in a European city. Theor. Appl. Climatol. 2017, 128, 43-61. [CrossRef]

28. Kaloustian, N.; Bechtel, B. Local Climatic Zoning and Urban Heat Island in Beirut. Procedia Eng. 2016, 169, 216-223. [CrossRef]

29. Stewart, I.D. A systematic review and scientific critique of methodology in modern urban heat island literature. Int. J. Climatol. 2011, 31, 200-217. [CrossRef]

30. Fenner, D.; Meier, F.; Bechtel, B.; Otto, M.; Scherer, D. Intra and inter 'local climate zone' variability of air temperature as observed by crowdsourced citizen weather stations in Berlin, Germany. Meteorol. Z. 2017, 26, 525-547. [CrossRef]

31. Quanz, J.A.; Ulrich, S.; Fenner, D.; Holtmann, A.; Eimermacher, J. Micro-Scale Variability of Air Temperature within a Local Climate Zone in Berlin, Germany, during Summer. Climate 2018, 6, 5. [CrossRef]

32. Bechtel, B.; Alexander, P.J.; Beck, C.; Böhner, J.; Brousse, O.; Ching, J.; Demuzere, M.; Fonte, C.; Gál, T.; Hidalgo, J.; et al. Generating WUDAPT Level 0 data-Current status of production and evaluation. Urban Clim. 2019, 27, 24-45. [CrossRef]

33. Wicki, A.; Parlow, E. Attribution of local climate zones using a multitemporal land use/land cover classification scheme. J. Appl. Remote Sens. 2017, 11, 026001. [CrossRef]

34. Ng, E.; Ren, C.; Katzschner, L.; Yau, R. Urban climatic studies for hot and humid tropical coastal city of Hong Kong. In Proceedings of the 5th Japanese-German Meeting on Urban Climatology, Freiburg, Germany, 6-8 October 2008; p. 265. 
35. Smith, C.; Cavan, G.; Lindley, S. Urban climatic map studies in UK: Greater Manchester. In The Urban Climatic Map; Routledge: Abingdon, UK, 2015; pp. 313-326.

36. $\mathrm{Hu}, \mathrm{X} . ; \mathrm{Xu}, \mathrm{H}$. A new remote sensing index for assessing the spatial heterogeneity in urban ecological quality: A case from Fuzhou City, China. Ecol. Indic. 2018, 89, 11-21. [CrossRef]

37. Alavipanah, S.; Schreyer, J.; Haase, D.; Lakes, T.; Qureshi, S. The effect of multi-dimensional indicators on urban thermal conditions. J. Clean. Prod. 2018, 177, 115-123. [CrossRef]

38. Alavipanah, S.; Haase, D.; Lakes, T.; Qureshi, S. Integrating the third dimension into the concept of urban ecosystem services: A review. Ecol. Indic. 2017, 72, 374-398. [CrossRef]

39. Aida, M. Urban albedo as a function of the urban structure-A model experiment. Bound. Layer Meteorol. 1982, 23, 405-413. [CrossRef]

40. Krayenhoff, E.S.; Voogt, J.A. A microscale three-dimensional urban energy balance model for studying surface temperatures. Bound. Layer Meteorol. 2007, 123, 433-461. [CrossRef]

41. Arnfield, A.J. Canyon geometry, the urban fabric and nocturnal cooling: A simulation approach. Phys. Geogr. 1990, 11, 220-239. [CrossRef]

42. Voogt, J.A.; Oke, T.R. Validation of an urban canyon radiation model for nocturnal long-wave fluxes. Bound. Layer Meteorol. 1991, 54, 347-361. [CrossRef]

43. Oke, T.R. The urban energy balance. Prog. Phys. Geogr. Earth Environ. 1988, 12, 471-508. [CrossRef]

44. Ward, H.; Grimmond, C. Assessing the impact of changes in surface cover, human behaviour and climate on energy partitioning across Greater London. Landsc. Urban Plan. 2017, 165, 142-161. [CrossRef]

45. Grimmond, C.S.B.; Oke, T.R. Heat Storage in Urban Areas: Local-Scale Observations and Evaluation of a Simple Model. J. Appl. Meteorol. 1999, 38, 922-940. [CrossRef]

46. Sailor, D.J. A review of methods for estimating anthropogenic heat and moisture emissions in the urban environment. Int. J. Climatol. 2011, 31, 189-199. [CrossRef]

47. Ferrante, A. Towards Nearly Zero Energy: Urban Settings in the Mediterranean Climate; Butterworth-Heinemann: Oxford, UK, 2016.

48. Maloutas, T. Socio-economic segregation in Athens at the beginning of the twenty-first century. In Socio-Economic Segregation in European Capital Cities: East Meets West; Routledge: Abingdon, UK, 2015; pp. 156-185.

49. Papamanolis, N. The main characteristics of the urban climate and the air quality in Greek cities. Urban Clim. 2015, 12, 49-64. [CrossRef]

50. Papageorgiou, M.; Gemenetzi, G. Setting the grounds for the green infrastructure in the metropolitan areas of Athens and Thessaloniki: The role of green space. Eur. J. Environ. Sci. 2018, 8, 83-92. [CrossRef]

51. Giannopoulou, K.; Livada, I.; Santamouris, M.; Saliari, M.; Assimakopoulos, M.; Caouris, Y.G. On the characteristics of the summer urban heat island in Athens, Greece. Sustain. Cities Soc. 2011, 1, 16-28. [CrossRef]

52. Kourtidis, K.; Georgoulias, A.K.; Rapsomanikis, S.; Amiridis, V.; Keramitsoglou, I.; Hooyberghs, H.; Maiheu, B.; Melas, D. A study of the hourly variability of the urban heat island effect in the Greater Athens Area during summer. Sci. Total Environ. 2015, 517, 162-177. [CrossRef] [PubMed]

53. Georgakis, C.; Santamouris, M. Determination of the Surface and Canopy Urban Heat Island in Athens Central Zone Using Advanced Monitoring. Climate 2017, 5, 97. [CrossRef]

54. Copernicus Land Monitoring Service. Urban Atlas 2012. Available online: https://land.copernicus.eu/local/ urban-atlas/urban-atlas-2012 (accessed on 14 March 2019).

55. Agathangelidis, I.; Cartalis, C. Improving the disaggregation of MODIS land surface temperatures in an urban environment: A statistical downscaling approach using high-resolution emissivity. Int. J. Remote Sens. 2019, 40, 5261-5286. [CrossRef]

56. Hellenic Statistical Authority (ELSTAT). Digital Cartographic Data. Available online: http://www.statistics. gr/en/digital-cartographical-data (accessed on 14 March 2019).

57. OpenStreetMap Contributors. Planet Dump. Available online: https://planet.osm.org (accessed on 2 February 2019).

58. Burian, S.J.; Velugubantla, S.P.; Brown, M.J. Morphological Analyses Using 3D Building Databases: Salt Lake City, Utah; LA-UR-02-6197, Los Alamos National Laboratory: Los Alamos, NM, USA, 2002. 
59. Jhaldiyal, A.; Gupta, K.; Gupta, P.K.; Thakur, P.; Kumar, P. Urban Morphology Extractor: A spatial tool for characterizing urban morphology. Urban Clim. 2018, 24, 237-246. [CrossRef]

60. Lindberg, F.; Grimmond, C.S.B.; Martilli, A. Sunlit fractions on urban facets-Impact of spatial resolution and approach. Urban Clim. 2015, 12, 65-84. [CrossRef]

61. Wong, M.S.; Nichol, J.E.; To, P.H.; Wang, J. A simple method for designation of urban ventilation corridors and its application to urban heat island analysis. Build. Environ. 2010, 45, 1880-1889. [CrossRef]

62. Chen, L.; $\mathrm{Ng}$, E. Quantitative urban climate mapping based on a geographical database: A simulation approach using Hong Kong as a case study. Int. J. Appl. Earth Obs. Geoinf. 2011, 13, 586-594. [CrossRef]

63. Bastiaanssen, W.G.M.; Menenti, M.; Feddes, R.A.; Holtslag, A.A.M. A remote sensing surface energy balance algorithm for land (SEBAL). 1. Formulation. J. Hydrol. 1998, 212-213, 198-212. [CrossRef]

64. Liu, S.; Lu, L.; Mao, D.; Jia, L. Evaluating parameterizations of aerodynamic resistance to heat transfer using field measurements. Hydrol. Earth Syst. Sci. 2007, 11, 769-783. [CrossRef]

65. Andreu, A.; Kustas, W.P.; Polo, M.J.; Carrara, A.; González-Dugo, M.P. Modeling Surface Energy Fluxes over a Dehesa (Oak Savanna) Ecosystem Using a Thermal Based Two-Source Energy Balance Model (TSEB) I. Remote Sens. 2018, 10, 567. [CrossRef]

66. Kato, S.; Yamaguchi, Y. Analysis of urban heat-island effect using ASTER and ETM+ Data: Separation of anthropogenic heat discharge and natural heat radiation from sensible heat flux. Remote Sens. Environ. 2005, 99, 44-54. [CrossRef]

67. Crawford, B.; Grimmond, S.B.; Gabey, A.; Marconcini, M.; Ward, H.C.; Kent, C.W. Variability of urban surface temperatures and implications for aerodynamic energy exchange in unstable conditions. Q. J.R. Meteorol. Soc. 2018, 144, 1719-1741. [CrossRef]

68. Chrysoulakis, N.; Grimmond, S.; Feigenwinter, C.; Lindberg, F.; Gastellu-Etchegorry, J.-P.; Marconcini, M.; Mitraka, Z.; Stagakis, S.; Crawford, B.; Olofson, F.; et al. Urban energy exchanges monitoring from space. Sci. Rep. 2018, 8, 11498. [CrossRef] [PubMed]

69. Lagouvardos, K.; Kotroni, V.; Bezes, A.; Koletsis, I.; Kopania, T.; Lykoudis, S.; Mazarakis, N.; Papagiannaki, K.; Vougioukas, S. The automatic weather stations NOANN network of the National Observatory of Athens: Operation and database. Geosci. Data J. 2017, 4, 4-16. [CrossRef]

70. Hudson, G.; Wackernagel, H. Mapping temperature using kriging with external drift: Theory and an example from Scotland. Int. J. Climatol. 1994, 14, 77-91. [CrossRef]

71. Macdonald, R.W.; Griffiths, R.F.; Hall, D.J. An improved method for the estimation of surface roughness of obstacle arrays. Atmos. Environ. 1998, 32, 1857-1864. [CrossRef]

72. Kent, C.W.; Grimmond, S.; Gatey, D. Aerodynamic roughness parameters in cities: Inclusion of vegetation. J. Wind Eng. Ind. Aerodyn. 2017, 169, 168-176. [CrossRef]

73. Kanda, M.; Kanega, M.; Kawai, T.; Moriwaki, R.; Sugawara, H. Roughness Lengths for Momentum and Heat Derived from Outdoor Urban Scale Models. J. Appl. Meteorol. Climatol. 2007, 46, 1067-1079. [CrossRef]

74. Kawai, T.; Ridwan, M.K.; Kanda, M. Evaluation of the Simple Urban Energy Balance Model Using Selected Data from 1-yr Flux Observations at Two Cities. J. Appl. Meteorol. Climatol. 2009, 48, 693-715. [CrossRef]

75. Nishida, K.; Nemani, R.R.; Running, S.W.; Glassy, J.M. An operational remote sensing algorithm of land surface evaporation. J. Geophys. Res. Atmos. 2003, 108. [CrossRef]

76. Kato, S.; Yamaguchi, Y.; Liu, C.-C.; Sun, C.-Y. Surface Heat Balance Analysis of Tainan City on March 6, 2001 Using ASTER and Formosat-2 Data. Sensors 2008, 8, 6026-6044. [CrossRef] [PubMed]

77. De Ridder, K.; Lauwaet, D.; Maiheu, B. UrbClim-A fast urban boundary layer climate model. Urban Clim. 2015, 12, 21-48. [CrossRef]

78. Daglis, I.A.; Rapsomanikis, S.; Kourtidis, K.; Melas, D.; Papayannis, A.; Keramitsoglou, I.; Giannaros, T.; Amiridis, V.; Petropoulos, G.; Georgoulias, A.; et al. Results of the DUE THERMOPOLIS campaign with regard to the urban heat island (UHI) effect in Athens. In Proceedings of the ESA Living Planet Symposium, Bergen, Norway, 28 June-2 July 2010.

79. Rapsomanikis, S.; Trepekli, A.; Loupa, G.; Polyzou, C. Vertical Energy and Momentum Fluxes in the Centre of Athens, Greece During a Heatwave Period (Thermopolis 2009 Campaign). Bound. Layer Meteorol. 2015, 154, 497-512. [CrossRef]

80. Sturm, P.; Eugster, W.; Knohl, A. Eddy covariance measurements of CO2 isotopologues with a quantum cascade laser absorption spectrometer. Agric. For. Meteorol. 2012, 152, 73-82. [CrossRef] 
81. Feigenwinter, C.; Vogt, R.; Parlow, E.; Lindberg, F.; Marconcini, M.; Del Frate, F.; Chrysoulakis, N. Spatial Distribution of Sensible and Latent Heat Flux in the City of Basel (Switzerland). IEEE J. Sel. Top. Appl. Earth Obs. Remote Sens. 2018, 11, 2717-2723. [CrossRef]

82. Kormann, R.; Meixner, F.X. An Analytical Footprint Model for Non-Neutral Stratification. Bound. Layer Meteorol. 2001, 99, 207-224. [CrossRef]

83. Lindberg, F.; Grimmond, C.S.B.; Gabey, A.; Huang, B.; Kent, C.W.; Sun, T.; Theeuwes, N.E.; Järvi, L.; Ward, H.C.; Capel-Timms, I.; et al. Urban Multi-scale Environmental Predictor (UMEP): An integrated tool for city-based climate services. Environ. Model. Softw. 2018, 99, 70-87. [CrossRef]

84. Grimmond, C.S.B.; Cleugh, H.A.; Oke, T.R. An objective urban heat storage model and its comparison with other schemes. Atmos. Environ. Part B Urban Atmos. 1991, 25, 311-326. [CrossRef]

85. Offerle, B.; Grimmond, C.S.B.; Fortuniak, K. Heat storage and anthropogenic heat flux in relation to the energy balance of a central European city centre. Int. J. Climatol. 2005, 25, 1405-1419. [CrossRef]

86. Crawford, B.; Krayenhoff, E.S.; Cordy, P. The urban energy balance of a lightweight low-rise neighborhood in Andacollo, Chile. Theor. Appl. Climatol. 2018, 131, 55-68. [CrossRef]

87. Loupa, G.; Rapsomanikis, S.; Trepekli, A.; Kourtidis, K. Energy flux parametrization as an opportunity to get Urban Heat Island insights: The case of Athens, Greece (Thermopolis 2009 Campaign). Sci. Total Environ. 2016, 542, 136-143. [CrossRef] [PubMed]

88. Roberts, S.M.; Oke, T.R.; Grimmond, C.S.B.; Voogt, J.A. Comparison of Four Methods to Estimate Urban Heat Storage. J. Appl. Meteorol. Climatol. 2006, 45, 1766-1781. [CrossRef]

89. Wicki, A.; Parlow, E.; Feigenwinter, C. Evaluation and modeling of urban heat island intensity in Basel, Switzerland. Climate 2018, 6, 55. [CrossRef]

90. Yoshida, A.; Tominaga, K.; Watatani, S. Field measurements on energy balance of an urban canyon in the summer season. Energy Build. 1990, 15, 417-423. [CrossRef]

91. Meyn, S.K.; Oke, T. Heat fluxes through roofs and their relevance to estimates of urban heat storage. Energy Build. 2009, 41, 745-752. [CrossRef]

92. Asaeda, T.; Ca, V.T. The subsurface transport of heat and moisture and its effect on the environment: A numerical model. Bound. Layer Meteorol. 1993, 65, 159-179. [CrossRef]

93. Nunez, M. The Energy Balance of an Urban Canyon. Ph.D. Thesis, University of British Columbia, Vancouver, BC, Canada, 1974.

94. Doll, D.; Ching, J.K.S.; Kaneshiro, J. Parameterization of subsurface heating for soil and concrete using net radiation data. Bound. Layer Meteorol. 1985, 32, 351-372. [CrossRef]

95. Fuchs, M.; Hadas, A. The heat flux density in a non-homogeneous bare loessial soil. Bound. Layer Meteorol. 1972, 3, 191-200. [CrossRef]

96. Pigeon, G.; Legain, D.; Durand, P.; Masson, V. Anthropogenic heat release in an old European agglomeration (Toulouse, France). Int. J. Climatol. 2007, 27, 1969-1981. [CrossRef]

97. Allen, L.; Lindberg, F.; Grimmond, C.S.B. Global to city scale urban anthropogenic heat flux: Model and variability. Int. J. Climatol. 2011, 31, 1990-2005. [CrossRef]

98. Lindberg, F.; Grimmond, C.S.B.; Yogeswaran, N.; Kotthaus, S.; Allen, L. Impact of city changes and weather on anthropogenic heat flux in Europe 1995-2015. Urban Clim. 2013, 4, 1-15. [CrossRef]

99. Dong, Y.; Varquez, A.C.G.; Kanda, M. Global anthropogenic heat flux database with high spatial resolution. Atmos. Environ. 2017, 150, 276-294. [CrossRef]

100. Kikegawa, Y.; Genchi, Y.; Yoshikado, H.; Kondo, H. Development of a numerical simulation system toward comprehensive assessments of urban warming countermeasures including their impacts upon the urban buildings' energy-demands. Appl. Energy 2003, 76, 449-466. [CrossRef]

101. Hamilton, I.G.; Davies, M.; Steadman, P.; Stone, A.; Ridley, I.; Evans, S. The significance of the anthropogenic heat emissions of London's buildings: A comparison against captured shortwave solar radiation. Build. Environ. 2009, 44, 807-817. [CrossRef]

102. Smith, C.; Lindley, S.; Levermore, G. Estimating spatial and temporal patterns of urban anthropogenic heat fluxes for UK cities: The case of Manchester. Theor. Appl. Climatol. 2009, 98, 19-35. [CrossRef]

103. Iamarino, M.; Beevers, S.; Grimmond, C.S.B. High-resolution (space, time) anthropogenic heat emissions: London 1970-2025. Int. J. Climatol. 2012, 32, 1754-1767. [CrossRef] 
104. Zheng, Y.; Weng, Q. High spatial- and temporal-resolution anthropogenic heat discharge estimation in Los Angeles County, California. J. Environ. Manag. 2018, 206, 1274-1286. [CrossRef] [PubMed]

105. Gabey, A.M.; Grimmond, C.S.B.; Capel-Timms, I. Anthropogenic heat flux: Advisable spatial resolutions when input data are scarce. Theor. Appl. Climatol. 2019, 135, 791-807. [CrossRef]

106. Dianeosis. The Impacts of Climate Change on Development. Available online: https://www.dianeosis.org/ wp-content/uploads/2017/06/climate_change10.pdf (accessed on 12 March 2019).

107. Psiloglou, B.E.; Giannakopoulos, C.; Majithia, S.; Petrakis, M. Factors affecting electricity demand in Athens, Greece and London, UK: A comparative assessment. Energy 2009, 34, 1855-1863. [CrossRef]

108. PEPESEC PROJECT. Indicative Results of The Electricity Measuring Campaign in the Municipality of Amaroussion (CRES). Available online: http://www.cres.gr/pepesec/apotelesmata_uk.html (accessed on 12 March 2019).

109. Independent Power Transmission Operator (ADMIE). Interconnections Net Flows (SCADA). Available online: http://www.admie.gr/en/operations-data/system-operation/real-time-data/reports/interconnectionsnet-flows-scada/ (accessed on 12 March 2019).

110. Hellenic Gas Transmission System Operator (DESFA). Historical Data of Natural Gas Deliveries. Available online: http://desfa.gr/en/regulated-services/transmission/pliroforisimetaforas-page/historicaldata/deliveries-offtakes (accessed on 12 March 2019).

111. Hellenic Ministry of Environment and Energy. Land Use. Available online: http://msa.ypeka.gr/index.php? lang=EN (accessed on 12 March 2019).

112. EMEP/EEA. EMEP/EEA Air Pollutant Emission Inventory Guidebook-2016. Available online: https: //www.eea.europa.eu/publications/emep-eea-guidebook-2016 (accessed on 12 March 2019).

113. Hellenic Statistical Authority (ELSTAT). Vehicle Fleet. Available online: http://www.statistics.gr/en/statistics/ -/publication/SME18/- (accessed on 12 March 2019).

114. European Automobile Manufacturers Association (ACEA). ACEA Report Vehicles in Use Europe 2017; ACEA: Brussels, Belgium, 2017.

115. Hellenic Association of Motor Vehicle Importers-Representatives (AMVIR). Annual Leaflet 2014; AMVIR: Halandri-Athens, Greece, 2014.

116. Fameli, K.-M.; Assimakopoulos, V.D. The new open Flexible Emission Inventory for Greece and the Greater Athens Area (FEI-GREGAA): Account of pollutant sources and their importance from 2006 to 2012. Atmos. Environ. 2016, 137, 17-37. [CrossRef]

117. Sailor, D.J.; Georgescu, M.; Milne, J.M.; Hart, M.A. Development of a national anthropogenic heating database with an extrapolation for international cities. Atmos. Environ. 2015, 118, 7-18. [CrossRef]

118. Stewart, I.D.; Kennedy, C.A. Metabolic heat production by human and animal populations in cities. Int. J. Biometeorol. 2017, 61, 1159-1171. [CrossRef] [PubMed]

119. Eurostat. GEOSTAT-2011. Available online: https://ec.europa.eu/eurostat/web/gisco/geodata/reference-data/ population-distribution-demography/geostat (accessed on 12 March 2019).

120. Greco, S.; Ishizaka, A.; Tasiou, M.; Torrisi, G. On the Methodological Framework of Composite Indices: A Review of the Issues of Weighting, Aggregation, and Robustness. Soc. Indic. Res. 2019, 141, 61-94. [CrossRef]

121. Jolliffe, I.T.; Cadima, J. Principal component analysis: A review and recent developments. Philos. Trans. R. Soc. A Math. Phys. Eng. Sci. 2016, 374, 20150202. [CrossRef] [PubMed]

122. Bandura, R. A Survey of Composite Indices Measuring Country Performance: 2008 Update; A UNDP/ODS Working Paper; United Nations Development Programme, Office of Development Studies: New York, NY, USA, 2008.

123. Krefis, A.C.; Schwarz, N.G.; Nkrumah, B.; Acquah, S.; Loag, W.; Sarpong, N.; Adu-Sarkodie, Y.; Ranft, U.; May, J. Principal component analysis of socioeconomic factors and their association with malaria in children from the Ashanti Region, Ghana. Malar. J. 2010, 9, 201. [CrossRef]

124. Geletič, J.; Lehnert, M. GIS-based delineation of local climate zones: The case of medium-sized Central European cities. Morav. Geogr. Rep. 2016, 24, 2-12. [CrossRef]

125. Wang, R.; Ren, C.; Xu, Y.; Lau, K.K.-L.; Shi, Y. Mapping the local climate zones of urban areas by GIS-based and WUDAPT methods: A case study of Hong Kong. Urban Clim. 2018, 24, 567-576. [CrossRef]

126. Zheng, Y.; Ren, C.; Xu, Y.; Wang, R.; Ho, J.; Lau, K.; Ng, E. GIS-based mapping of Local Climate Zone in the high-density city of Hong Kong. Urban Clim. 2018, 24, 419-448. [CrossRef] 
127. Mitraka, Z.; Del Frate, F.; Chrysoulakis, N.; Gastellu-Etchegorry, J.-P. Exploiting earth observation data products for mapping local climate zones. In Proceedings of the 2015 Joint Urban Remote Sensing Event (JURSE), Lausanne, Switzerland, 30 March-1 April 2015; pp. 1-4.

128. Giorgi, F.; Jones, C.; Asrar, G.R. Addressing climate information needs at the regional level: The CORDEX framework. World Meteorol. Organ. (WMO) Bull. 2009, 58, 175.

129. Hellenic Statistical Authority (ELSTAT). Survey on Energy Consumption in Households, 2011-2012; ELSTAT: Piraeus, Greece, 2013.

130. Ward, H.C.; Kotthaus, S.; Järvi, L.; Grimmond, C.S.B. Surface Urban Energy and Water Balance Scheme (SUEWS): Development and evaluation at two UK sites. Urban Clim. 2016, 18, 1-32. [CrossRef]

131. Johnson, G.T.; Oke, T.R.; Lyons, T.J.; Steyn, D.G.; Watson, I.D.; Voogt, J.A. Simulation of surface urban heat islands under 'IDEAL' conditions at night part 1: Theory and tests against field data. Bound. Layer Meteorol. 1991, 56, 275-294. [CrossRef]

132. Hu, D.; Yang, L.; Zhou, J.; Deng, L. Estimation of urban energy heat flux and anthropogenic heat discharge using aster image and meteorological data: Case study in Beijing metropolitan area. J. Appl. Remote Sens. 2012, 6, 063559. [CrossRef]

133. Liu, K.; Fang, J.; Zhao, D.; Liu, X.; Zhang, X.; Wang, X.; Li, X. An Assessment of Urban Surface Energy Fluxes Using a Sub-Pixel Remote Sensing Analysis: A Case Study in Suzhou, China. ISPRS Int. J. Geo-Inf. 2016, 5, 11. [CrossRef]

134. Weng, Q.; Hu, X.; Quattrochi, D.A.; Liu, H. Assessing Intra-Urban Surface Energy Fluxes Using Remotely Sensed ASTER Imagery and Routine Meteorological Data: A Case Study in Indianapolis, U.S.A. IEEE J. Sel. Top. Appl. Earth Obs. Remote Sens. 2014, 7, 4046-4057. [CrossRef]

135. Wong, M.S.; Yang, J.; Nichol, J.; Weng, Q.; Menenti, M.; Chan, P. Modeling of Anthropogenic Heat Flux Using HJ-1B Chinese Small Satellite Image: A Study of Heterogeneous Urbanized Areas in Hong Kong. IEEE Geosci. Remote Sens. Lett. 2015, 12, 1466-1470. [CrossRef]

136. Xu, W.; Wooster, M.J.; Grimmond, C.S.B. Modelling of urban sensible heat flux at multiple spatial scales: A demonstration using airborne hyperspectral imagery of Shanghai and a temperature-emissivity separation approach. Remote Sens. Environ. 2008, 112, 3493-3510. [CrossRef]

137. Zhang, Y.; Balzter, H.; Wu, X. Spatial-temporal patterns of urban anthropogenic heat discharge in Fuzhou, China, observed from sensible heat flux using Landsat TM/ETM+ data. Int. J. Remote Sens. 2013, 34, 1459-1477. [CrossRef]

138. Zhou, Y.; Weng, Q.; Gurney, K.R.; Shuai, Y.; Hu, X. Estimation of the relationship between remotely sensed anthropogenic heat discharge and building energy use. ISPRS J. Photogramm. Remote Sens. 2012, 67, 65-72. [CrossRef]

139. Zhan, W.; Chen, Y.; Zhou, J.; Wang, J.; Liu, W.; Voogt, J.; Zhu, X.; Quan, J.; Li, J. Disaggregation of remotely sensed land surface temperature: Literature survey, taxonomy, issues, and caveats. Remote Sens. Environ. 2013, 131, 119-139. [CrossRef]

140. Sailor, D.J.; Lu, L. A top-down methodology for developing diurnal and seasonal anthropogenic heating profiles for urban areas. Atmos. Environ. 2004, 38, 2737-2748. [CrossRef]

141. Ichinose, T.; Shimodozono, K.; Hanaki, K. Impact of anthropogenic heat on urban climate in Tokyo. Atmos. Environ. 1999, 33, 3897-3909. [CrossRef]

142. Moriwaki, R.; Kanda, M.; Senoo, H.; Hagishima, A.; Kinouchi, T. Anthropogenic water vapor emissions in Tokyo. Water Resour. Res. 2008, 44. [CrossRef]

143. Antonopoulou, S. Postwar Transformation of the Greek Economy and the Residential Phenomenon; Papazisis: Athens, Greece, 1991.

144. Alexandri, G. Planning Gentrification and the 'Absent' State in Athens. Int. J. Urban Reg. Res. 2018, 42, 36-50. [CrossRef]

145. Leontidou, L.; Emmanuel, L.L.; Lila, L. The Mediterranean City in Transition: Social Change and Urban Development; Cambridge University Press: Cambridge, UK, 1990.

146. Mantouvalou, M.; Mavridou, M.; Vaiou, D. Processes of social integration and urban development in Greece: Southern challenges to European unification. Eur. Plan. Stud. 1995, 3, 189-204. [CrossRef]

147. Maloutas, T. The Social and Economic Atlas of Greece, Volume I: The Cities National Centre for Social Research; EKKE-University of Thessaly Press: Athens/Volos, Greece, 2000. 
148. Kalogirou, S. Spatial inequalities and interpretative factors for the geographical distribution of declared income in Greece. Aihoros 2011, 11, 68-101.

149. Panori, A. A tale of hidden cities. REGION 2017, 4, 19-38. [CrossRef]

150. Eskeland, G.S.; Mideksa, T.K. Electricity demand in a changing climate. Mitig. Adapt. Strateg. Glob. Chang. 2010, 15, 877-897. [CrossRef]

151. Asimakopoulos, D.; Santamouris, M.; Farrou, I.; Laskari, M.; Saliari, M.; Zanis, G.; Giannakidis, G.; Tigas, K.; Kapsomenakis, J.; Douvis, C.; et al. Modelling the energy demand projection of the building sector in Greece in the 21st century. Energy Build. 2012, 49, 488-498. [CrossRef]

152. Paravantis, J.; Santamouris, M.; Cartalis, C.; Efthymiou, C.; Kontoulis, N. Mortality Associated with High Ambient Temperatures, Heatwaves, and the Urban Heat Island in Athens, Greece. Sustainability 2017, 9, 606. [CrossRef]

(C) 2019 by the authors. Licensee MDPI, Basel, Switzerland. This article is an open access article distributed under the terms and conditions of the Creative Commons Attribution (CC BY) license (http://creativecommons.org/licenses/by/4.0/). 